University of Nebraska - Lincoln

DigitalCommons@University of Nebraska - Lincoln

1993

Seismotectonics of the San Andreas Fault System Between Point Arena and Cape Mendocino in Northern California' Implications for the Development and Evolution of a Young Transform

\author{
David A. Castillo \\ Stanford University \\ William L. Ellsworth \\ U.S. Geological Survey
}

Follow this and additional works at: https://digitalcommons.unl.edu/usgsstaffpub

Part of the Earth Sciences Commons

Castillo, David A. and Ellsworth, William L., "Seismotectonics of the San Andreas Fault System Between Point Arena and Cape Mendocino in Northern California' Implications for the Development and Evolution of a Young Transform" (1993). USGS Staff -- Published Research. 387.

https://digitalcommons.unl.edu/usgsstaffpub/387

This Article is brought to you for free and open access by the US Geological Survey at DigitalCommons@University of Nebraska - Lincoln. It has been accepted for inclusion in USGS Staff -- Published Research by an authorized administrator of DigitalCommons@University of Nebraska - Lincoln. 


\title{
Seismotectonics of the San Andreas Fault System Between Point Arena and Cape Mendocino in Northern California: Implications for the Development and Evolution of a Young Transform
}

\author{
David A. Castillo ${ }^{1}$ and William L. Ellsworth \\ U.S. Geological Survey, Menlo Park, California
}

\begin{abstract}
The northernmost and relatively youthful segment of the San Andreas fault system is situated within a $100+\mathrm{km}$ wide zone of northwest trending strike-slip faults that includes, from west to east, the San Andreas, Maacama, and Bartlett Springs faults. Although the San Andreas fault is the principal strike-slip fault in this system, it has been virtually aseismic since the 1906 earthquake. Moderate levels of seismicity locate to the east along the Maacama fault and, to a lesser extent, the Bartlett Springs fault at focal depths typical of other strike-slip faults within the San Andreas fault system in central California. North of the San Andreas fault system, within the Cape Mendocino area, earthquakes occur at depths of up to $40 \mathrm{~km}$ and primarily reflect internal deformation of the subducting Gorda slab, and slip along the Mendocino Fracture Zone. Seismicity along the Maacama and Bartlett Springs faults is dominated by right-lateral to oblique-reverse slip along fault planes that dip $50^{\circ}-75^{\circ}$ to the northeast. The northern extent of seismicity along these faults terminates near the surface projection of the southern edge of the Gorda slab. The onset of seismicity along these faults may be related to the abrupt change in the elastic thickness of the North American plate as it enters the asthenospheric window. The Maacama and Bartlett Springs faults are strike-parallel with active reverse faults within the forearc region of the Cascadia subduction zone. This preexisting structural fabric of northwest trending reverse faults in the forearc area appears to have strongly influenced the initial slip and complexity of these faults. Continuation of the moderately dipping Maacama fault to the southeast along the steeply dipping Healdsburg and Rodgers Creek fault zones and the near-vertical Hayward and Calaveras fault zones in the San Francisco Bay area suggests that these faults evolve toward a more vertical dip to minimize the shear stresses that tend to resist plate motion.
\end{abstract}

\section{INTRODUCTION}

The San Andreas fault system in northern California accommodates relative motion between the Pacific and North American plates across a $100+\mathrm{km}$ wide zone of distributed right-lateral shear. The seismicity associated with different members of this fault system form a network of northward branching faults (Figure 1) that include the San Andreas fault to the west; the Hayward, Rodgers Creek, Healdsburg, and Maacama fault zones just east of the San Andreas and farther to the east, the Calaveras, Concord, Green Valley, and Bartlett Springs faults [Herd and Helley, 1977; Hill et al., 1990].

A decade of contemporary microseismicity along the northern San Andreas fault system has been used to characterize the style of faulting associated with this broad transform boundary beginning at the onset of strike-slip motion near and southeast of the Mendocino triple junction and southward to the latitude of Point Arena. We estimated the crustal velocity structure using earthquake travel time data to relocate over $5500 M_{L}>1.5$ earthquakes between Point Arena and Cape Mendocino for the period 1980-1991.

We found that the right-lateral transform motion on the seismically active Maacama and Bartlett Springs fault zones occurs along northeast dipping faults $\left(50^{\circ}-75^{\circ}\right)$. These faults were presumably formed as reverse faults within the forearc region of the Cascadia subduction zone but were left behind

\footnotetext{
${ }^{1}$ Now at Department of Geophysics, Stanford University, Stanford, California.

This paper is not subject to U.S. copyright. Published in 1993 by the American Geophysical Union.

Paper number 92JB02866.
}

in the wake of the migrating triple junction to accommodate Pacific-North American plate motion. The onset of strikeslip motion on these dipping faults occurs immediately south of the southern edge of the Gorda slab and appears to maintain this geometry southward for about $120 \mathrm{~km}$ (Figure 1).

\section{Tectonic SetTing}

The development and evolution of the San Andreas fault system in northern California are closely tied to the northward migration of the Mendocino triple junction [Dickinson and Synder, 1979; Lachenbruch and Sass, 1973, 1980] and possibly to the formation and evolution of the inferred asthenospheric "window" immediately south of the Gorda slab [Jachens and Griscom, 1983; Furlong et al., 1989]. The geometric complexity of the San Andreas fault system north of the San Francisco Bay area is, in part, the result of plate boundary adjustments due to geometric instabilities [ $\mathrm{McK}$ enzie and Morgan, 1969], recent (3.2-5.0 Ma) changes in absolute plate motions [Cox and Engebretson, 1985; Engebretson et al., 1986; Pollitz, 1986; Harbert and Cox, 1989] and ongoing northward migration of the Mendocino Triple Junction [Atwater, 1989; Griscom and Jachens, 1989]. South of Point Arena, the $\sim 100-\mathrm{km}$-wide, northwest-southeast trending Pacific-North American plate boundary is defined by the San Andreas fault to the west and the CalaverasHayward-Rodgers Creek-Healdsburg fault zones to the east (Figure 1). The San Andreas fault has been well mapped south of Point Arena [Herd and Helley, 1977; Prentice, 1989], but to the north where the fault becomes submarine, the lack of microseismicity makes it difficult to precisely identify the fault. Surface disturbances associated with the 1906 San Francisco earthquake at Point Delgada [Lawson et 


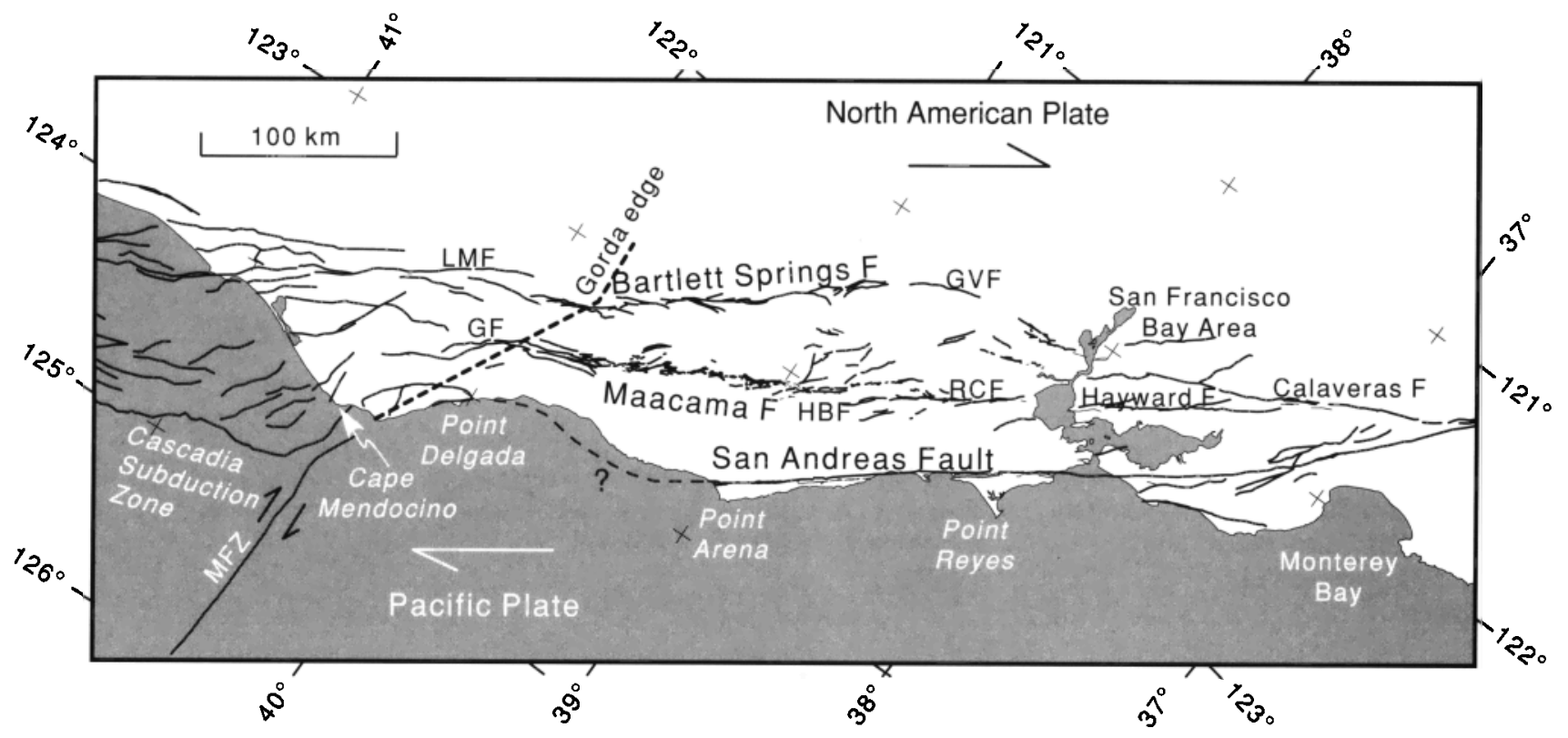

Fig. 1. Tectonic map of northern California showing active traces of Holocene and Quaternary faulting. Sources of the fault compilation for the offshore area and onshore projection include Clarke [1992] and for the onshore area, Kelsey and Carver [1988], Pampeyan et al. [1981], and Herd and Helley [1977]. The map projection is a oblique Transverse Mercator about the North American-Pacific pole of plate motion [DeMets et al., 1990]. All horizontal lines in this figure correspond to a small circle describing transform slip. MFZ, Mendocino fracture zone; GF, Garberville fault; LMF, Lake Mountain fault; HBF, Healdsburg fault; RCF, Rodgers Creek fault; HF, Hayward fault; CF, Calaveras fault; GV, Green Valley fault. The bold dashed line is the surface projection of the southern edge of the Gorda slab.

al., 1908; Brown and Wolf, 1972] and offshore seismic reflection data showing relatively young scarp faces [Curray and Nason, 1967; McCulloch, 1987] indicate that the San Andreas fault may make a $20^{\circ}$ clockwise bend just north of Point Arena and return onshore again at Point Delgada (Figure 1).

A tectonic map of the northern San Andreas fault system is shown in Figure 1 using an oblique Transverse Mercator projection about the pole $\left(49.6^{\circ} \mathrm{N}, 76.6^{\circ} \mathrm{W}\right)$ of relative plate motion for the North America and Pacific plates based on NUVEL I [DeMets et al., 1990]. The San Andreas fault between the area just north of Monterey Bay and Point Arena and, to the east, the Hayward, Rodgers Creek, and Healdsburg faults lie on small circle paths defined by this pole (Figure 1). However, the Maacama fault is slightly oblique $\left(10^{\circ}-15^{\circ}\right.$ to the east) to a small circle (Figure 1$)$. This $10^{\circ}-15^{\circ}$ sense of obliqueness in the strike of the Maacama fault, with respect to direction of North America and Pacific plate motion, appears to continue northward into the forearc region of the Cascadia subduction zone (Figure 1).

Ongoing convergence in northern California, between the Gorda and North American plates is partially expressed as compressional deformation within the forearc region of the southern Cascadia subduction zone and is characterized by a fold and thrust belt that is about $\mathbf{9 0 - 1 0 0 ~} \mathrm{km}$ wide [Clarke, 1992]. These structural features consist of Neogene to Quaternary accretionary folds and low-high angle reverse faults that strike northwest-southeast [Kelsey and Carver, 1988; Clarke, 1992]. Previous mapping of the northwest-southeast trending, northeast dipping Garberville and Lake Mountain faults located along the eastern extent of this fold and thrust belt (Figure 1) interpreted a narrow $\sim 50-\mathrm{km}$-wide domain associated with faults showing reverse and right-lateral motion [Kelsey and Carver, 1988]. The amount of translation that has occurred along these faults is uncertain, but recent mapping has suggested that there might have been at least 1-2 km of lateral translation along the Garberville fault since the Late Cenozoic (G. A. Carver, Humboldt State University, personal communication, 1992). Lateral slip along the Lake Mountain fault is less certain and inferred from alignment of sag ponds, pressure ridges, and other geomorphic lines of evidence.

Jachens and Griscom [1983] interpreted gradients in the magnetic field and isostatic residual gravity field in northern California to mark the southern edge of the Gorda plate where it has subducted beneath the North American plate (Figure 1). The southeast trend of the inferred slab edge between Cape Mendocino and the Bartlett Springs fault area parallels the current direction of plate motion for the Pacificsouthern Juan de Fuca (Gorda) plates. The eastern and deeper trend parallels the plate motion direction at $\sim 3.5 \mathrm{Ma}$ [Riddihough, 1984]. Jachens and Griscom [1983] show that the top of the Gorda slab is at about $7-8 \mathrm{~km}$ depth beneath Cape Mendocino and deepens to a depth of $20 \mathrm{~km}$, about 120 km to the southeast near where the Bartlett Springs fault terminates (Figure 1). Interpretation of the gravity data for slab position east of the Bartlett Springs fault is difficult because the signature of the slab is masked by the overlying Great Valley Sequence [Jachens and Griscom, 1983]. East of Cape Mendocino and beneath the Great Valley, seismicity data define a $20^{\circ}-30^{\circ}$ dipping Wadati-Benioff zone associated with the Gorda slab extending down to 80-90 km depths [Cockerham, 1984; Walter, 1986; Dewey et al., 1989].

The Coast Ranges of northern California are associated with a broad, heat flow high which appears to increase in amplitude southward from Cape Mendocino and reaches a 
maximum about $250 \mathrm{~km}$ south of the triple junction. Presumably, this is a consequence of the northward migration of the triple junction and the Gorda plate that leaves in its wake an asthenospheric "window" below the North American plate immediately south of the Gorda slab [Dickinson and Synder, 1979; Lachenbruch and Sass, 1980]. Lachenbruch and Sass [1980] suggested that the lithosphere beneath the Coast Ranges thickens to the south by thermal accretion with the heat source situated in the mid to upper crust $(\leq 20 \mathrm{~km}$ depth).

Furlong et al. [1989] suggests that the geometry of the lower crust/upper mantle transform plate boundary between the Pacific and North American plates has both spatial and temporal temperature dependencies, such that immediately south of the triple junction the lithospheric plate boundary does not correspond to the surface trace of the San Andreas fault, but is located about $\mathbf{3 0 - 4 0} \mathbf{~ k m}$ east. The upper mantle temperatures predicted from the Furlong et al. [1989] model attain their shallowest position east of the San Andreas fault, about where the Maacama and Bartlett Springs faults are located. As a consequence, the thermal-mechanical model predicts localized weakening in the lower crust which would subsequently lead to transform-related deformation (seismic and geodetic) within the upper crust [Furlong et al., 1989]. Furlong et al. [1989] suggested that the contemporary seismicity from the northern end of the Maacama fault southward to the Hayward/Calaveras fault zone (Figure 1) may be due to the thermally induced weakening of the lower crust.

\section{Seismicity Data}

The primary focus of this study is the analysis of contemporary seismicity within the northern San Andreas fault system between Point Arena and Cape Mendocino (Figure 2). Prior to 1980, the seismic network in northern California was composed of a few U.S. Geological Survey (USGS) and University of California, Berkeley, stations [Klein et al., 1988]. The stations in the TERA Corporation network in the Mendocino area were in operation between 1974 to 1986 . In 1980, an expansion of the USGS Northern California Network was completed, which brought the total of recording stations to 65 in the region between Clear Lake and Cape Mendocino (Figure 2). Seismicity recorded over the period from 1980 to 1991 provides the data used in this study. Selected events are within the magnitude range of $1.5 \leq M \leq 4.5$ (duration magnitudes). Only one earthquake larger than $M 5$ (1962 local magnitude $M_{L} 5.2,39.1^{\circ} \mathrm{N}$ $123.3^{\circ} \mathrm{W}, 20 \mathrm{~km}$ southwest of Ukiah) has occurred in this region since the 1906 San Francisco earthquake [Bolt and Miller, 1975; Toppozada and Cramer, 1978; Ellsworth et al., 1981; Ellsworth, 1990].

\section{Crustal Structure and Velocity Model}

The Coast Ranges of northern California are composed primarily of the Franciscan Complex with structure dominated by widespread northwest trending faults, folds, and melange fabrics [Jennings et al., 1977; Jones et al., 1978]. Because of the likely geologic variations within the Franciscan assemblages in this study area [Jennings et al., 1977], we determined local variations in velocity structure and station delays throughout the region (Figure 2) using the computer program VELEST [Roecker, 1981; Kraadolfer,

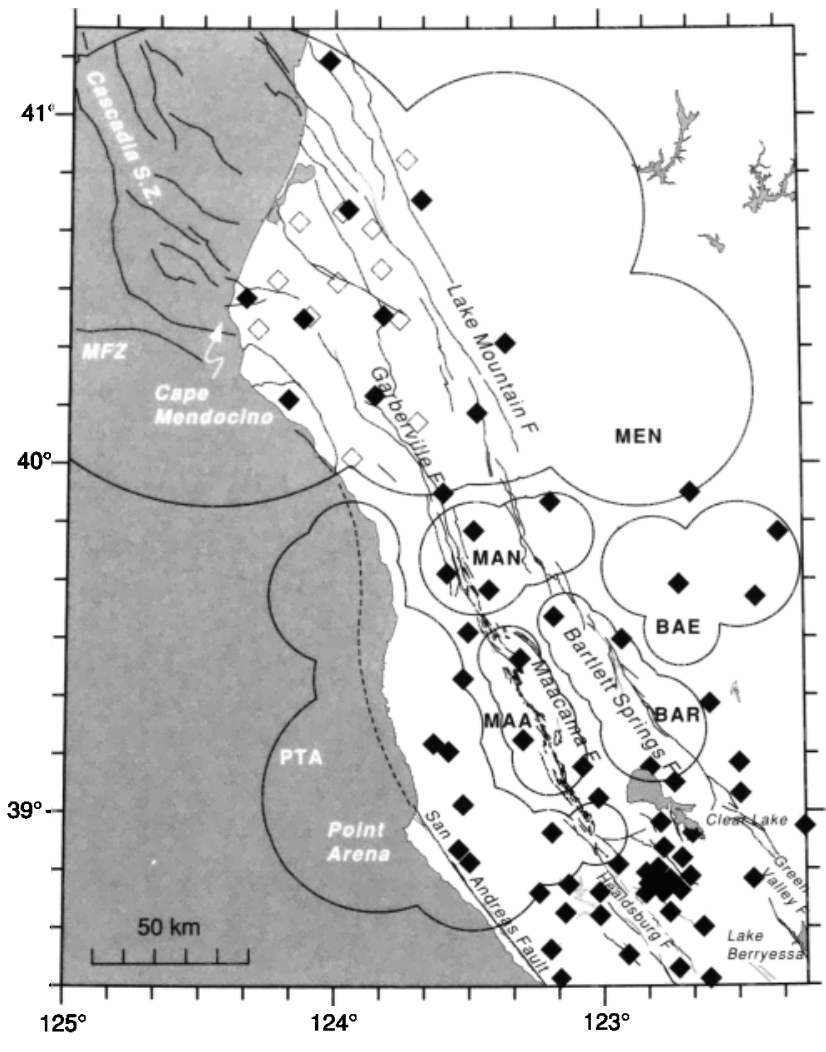

Fig. 2. Map of the northern California U.S. Geological Survey seismic network (solid diamonds) since 1980 [Klein et al., 1988]. The open diamonds depict the locations of a seismic network in the Cape Mendocino area operated by TERA Corporation for Pacific Gas and Electric between 1976 and 1984 . The solid lines formed by superposition of circles correspond to regions where the velocity structure and station corrections were computed. The velocity structure outside and between regions varies as a cosine taper. The velocity models: MAA (Maacama), MAN (Maacama north), BAE (Bartlett Springs east), BAR (Bartlett), PTA (Point arena), and MEN (Mendocino) are plotted in Figure 3 and listed in Table 1. Station corrections are listed in Table 2.

1989]. This algorithm simultaneously estimates hypocenter and velocity parameters to determine a series of onedimensional (1-D) velocity models and associated station delays for specific geographic locations as shown in Figure 2. Over 450 events of $M \geq 2$ recorded by 10 or more stations were used to estimate these parameters. The number of events used in each model shown in Figure 2 is provided in Table 1.

Source regions for which 1-D velocity models and related station delays were developed include the Maacama and the Bartlett Springs fault zones, regions east and west of the Bartlett Springs fault zone, the northern termination of the Maacama and Bartlett Springs faults, the Point Arena and coastal areas, and the Cape Mendocino region (Figure 2). Each source region was divided into specific subregions to better image the spatial variation in seismicity within the study area [Hill et al., 1990] and to model potential east-west variations in the mineral/textural assemblages of the Franciscan Complex [Jennings et al., 1977].

Diagonal elements of the resolution $\mathbf{R}$ matrix used in the generalized inverse scheme for velocity layers within the $\mathbf{3 . 5}$ to $12.5 \mathrm{~km}$ depth range had values between 0.85 and 0.95 , and standard errors that ranged from 0.01 to $0.02 \mathrm{~km} / \mathrm{s}$. This 
TABLE 1. Table of Velocity Models Used in This Study

\begin{tabular}{lrrrrrr}
\hline & \multicolumn{5}{c}{ Velocity, km/s } \\
\cline { 2 - 7 } & MAA & MAN & BAE & BAR & PTA & MEN \\
\hline $\begin{array}{l}\text { Depth, km } \\
0.0\end{array}$ & 4.15 & 4.36 & 4.43 & 4.39 & 4.40 & 4.11 \\
1.0 & 4.65 & & & & & \\
1.5 & & 5.46 & 5.12 & 5.54 & 5.30 & 5.56 \\
2.5 & 5.49 & & & & & \\
3.5 & & 5.60 & 5.76 & 5.62 & 5.56 & 5.66 \\
4.0 & 5.57 & & & & & \\
5.0 & & 5.63 & 5.79 & 5.65 & 5.66 & 5.69 \\
6.5 & 5.63 & & & & & \\
7.5 & & 5.66 & 5.95 & 5.72 & 5.67 & 5.75 \\
8.0 & 5.72 & & & & & \\
10.0 & 5.81 & 5.78 & 5.97 & 5.79 & 5.68 & 5.80 \\
12.0 & 5.86 & & & & & \\
12.5 & & 6.00 & 5.99 & 5.97 & 5.85 & 5.86 \\
14.0 & 5.91 & & & & & \\
15.0 & & 6.21 & 6.08 & 6.08 & 6.08 & 5.96 \\
16.0 & 6.08 & & & & & \\
20.0 & 6.68 & 6.68 & 6.68 & 6.68 & 6.68 & 7.52 \\
25.0 & 7.76 & 7.76 & 7.76 & 6.78 & 7.76 & 7.88 \\
30.0 & 7.80 & 7.80 & 7.80 & 7.80 & 7.80 & 7.90 \\
Number of & 169 & 169 & 40 & 191 & 146 & 132 \\
events & & & & & & \\
\hline
\end{tabular}

Note that velocities below $20 \mathrm{~km}$ for each model, with the exception of model MEN, could not be constrained due to a lack of ray path coverage. Also shown are the number of events used in the calculation of each model.

suggests that this series of one-dimensional (1-D) velocity models is a reliable representation of the average crustal velocity structure, at least in areas of ample seismic coverage. Areas of dense seismicity was used to determine the 1-D velocity structure (Figure 2). Earthquakes falling outside the circled regions are located using a weighted-average between models. Earthquakes situated outside all of the models were located with the MAA model. Refinements in the average velocity structure reduced the data misfit which improved the relative location accuracy and provided the means to generate focal mechanism with improved takeoff angles. Absolute errors are unknown since we did not have explosive data. The regions encompassed by the six velocity models are shown in Figure 2, and the models and the associated station corrections are provided in Tables 1 and 2 .

The average velocity structure in the vicinity of the Maacama and Bartlett Springs fault zones are similar (Figure 3 ). The $P$ wave velocity structure for the upper $2 \mathrm{~km}$ ranges between 3.5 and $4.75 \mathrm{~km} / \mathrm{s}$ and is underlain by a steep velocity gradient in a $10-13 \mathrm{~km}$ thick layer with velocities of $5.40 \mathrm{~km} / \mathrm{s}$ at the top, increasing to $5.90 \mathrm{~km} / \mathrm{s}$ at the base. The deeper earthquakes in the Mendocino area indicate that the $5.9 \mathrm{~km} / \mathrm{s}$ velocities continue to about $18 \mathrm{~km}$ before encountering a velocity increase to $6.8 \mathrm{~km} / \mathrm{s}$ (Figure 3 and Table 1). This velocity model is similar to the velocity models for the Franciscan Complex based on three-dimensional (3-D) velocity analysis south of Clear Lake along the southern Maacama and Healdsburg faults [Eberhart-Phillips, 1986] and on explosion refraction experiments south of the San Francisco Bay area [Walter and Mooney, 1982], implying that the Franciscan Complex in the northern California Coast Ranges [Jennings et al., 1977] continues down to at least $15-20 \mathrm{~km}$ depth.

Using the six VELEST 1-D velocity results (Figure 3 and
Table 1), we relocated the 1980-1991 seismicity (Figure 4) using the hypocentral location program HYPOINVERSE [Klein, 1989]. Focal mechanisms of representative earthquakes (Figure 5) were computed and displayed using FPFIT and FPPLOT [Reasenberg and Oppenheimer, 1985].

\section{Seismotectonics of the Northern San Andreas Fault System}

The results of relocating the earthquakes for the 1980-1991 period (Figures 4-9) illustrate the spatial distribution, the fault geometry, and the dominate pattern of seismic strain release for the area between Point Arena and Cape Mendocino. Earthquakes shown in Figures 4-9 are of magnitude $M \geq 1.5$, with a root-mean-square (rms) $\leq 0.15 \mathrm{~s}$, standard horizontal error $\leq 1.0 \mathrm{~km}$, and standard vertical error $\leq 2.5$ $\mathrm{km}$. Earthquake focal mechanisms discussed in the text can be found in Table 3 and in Figure 10.

\section{San Andreas Fault}

During the 1980-1991 observation period, the section of the San Andreas fault that ruptured during the 1906 earthquake has been relatively aseismic (Figure 4). Near Point Arena, a few earthquakes locate $2-5 \mathrm{~km}$ to the west of the San Andreas fault, where the crust is pervasively faulted and folded (Figure 4; profile $J$ and $K$ in Figure 9) [Jennings et al., 1977]. The sparse seismic network coverage along the coast (Figure 2) makes it difficult to accurately constrain the faulting mechanisms. Nonetheless, some of these events are compatible with right-lateral motion on northwest trending nodal planes (earthquakes 23 and 36 in Figure 5). With the location accuracy, these events may, in fact, lie on the San Andreas fault proper.

A few events (earthquakes 33, 46, and 57 in Figure 5) located southeast of Point Arena and along the San Andreas fault indicate oblique right-lateral motion on north to northnorthwest trending planes, with $\boldsymbol{P}$ axes trending approximately normal to the San Andreas fault (Figure 6). This pattern of $\boldsymbol{P}$ axes orientations may be indicative of faultnormal compression as seen in central California [Zoback et al., 1987; Mount and Suppe, 1987]. Improved seismic coverage, however, is necessary to adequately constrain these mechanisms.

\section{Maacama Fault Zone}

The Maacama fault zone has been geologically mapped from $-39^{\circ} 50^{\prime} \mathrm{N}$ latitude, near the town of Laytonville, as a series of en echelon faults to $\sim 38^{\circ} 50^{\prime} \mathrm{N}$ latitude where the fault zone steps to the west onto the Healdsburg fault [Pampeyan et al., 1981; Upp, 1982]. Along its southern reaches, the fault follows the Ukiah Valley near the town of Willits, but farther north the surface fault trace does not have a clear geomorphic expression, where the fault commonly crosses ridge tops, indicative of a young fault without a long slip history [Pampeyan et al., 1981].

In map view, the Maacama fault zone has an apparent width of 15-25 km (Figure 4). Transverse cross sections of the seismicity along the Maacama fault defines northeast dipping structures that we interpret to represent discrete active fault strands (Figure 7 and profiles $F, G$, and $H$ in Figure 9). Figure 9 shows, in back hemisphere projection, representative focal mechanisms which are dominantly 
TABLE 2. Station Locations and the Calculated Station Delays Generated for Each Velocity Model Used in This Study

\begin{tabular}{|c|c|c|c|c|c|c|c|c|}
\hline Station & $\begin{array}{l}\text { Latitude } \\
\text { N }\end{array}$ & $\begin{array}{c}\text { Longitude } \\
\text { W }\end{array}$ & MAA & MAN & BAE & BAR & PTA & MEN \\
\hline BRYT & $40^{\circ} 43.53^{\prime}$ & $123^{\circ} 58.40^{\prime}$ & $0.00(38)$ & -0.17 & -0.17 & -0.17 & -0.17 & $-0.21(38)$ \\
\hline BZDT & $40^{\circ} 31.62^{\prime}$ & $124^{\circ} 13.13^{\prime}$ & 0.21 & 0.21 & 0.21 & 0.21 & 0.21 & 0.18 \\
\hline DIAT & $40^{\circ} 24.83^{\prime}$ & $123^{\circ} 45.45^{\prime}$ & 0.15 & $0.04(12)$ & -0.15 & -0.15 & 0.34 & $-0.16(72)$ \\
\hline EKRT & $40^{\circ} 41.72^{\prime}$ & $124^{\circ} 08.37^{\prime}$ & -0.28 & -0.28 & -0.28 & -0.28 & -0.28 & -0.32 \\
\hline FOXT & $40^{\circ} 31.27^{\prime}$ & $123^{\circ} 59.53^{\prime}$ & 0.11 & 0.11 & 0.11 & 0.11 & 0.02 & $0.09(65)$ \\
\hline GAFM & $38^{\circ} 53.59^{\prime}$ & $123^{\circ} 32.28^{\prime}$ & $0.24(11)$ & 0.14 & 0.08 & $0.13(09)$ & $0.10(15)$ & 0.08 \\
\hline GARM & $38^{\circ} 57.31^{\prime}$ & $122^{\circ} 15.13^{\prime}$ & $1.21(08)$ & 0.14 & $1.56(03)$ & $1.17(16)$ & $0.69(02)$ & 0.14 \\
\hline GASW & $39^{\circ} 39.29^{\prime}$ & $122^{\circ} 42.91^{\prime}$ & $0.30(80)$ & $0.08(90)$ & $0.02(18)$ & $-0.02(117)$ & $0.24(06)$ & $0.09(23)$ \\
\hline GAXM & $38^{\circ} 42.65^{\prime}$ & $122^{\circ} 45.30^{\prime}$ & -0.44 & -0.06 & -0.06 & $-0.15(06)$ & $-0.41(50)$ & -0.10 \\
\hline GBDM & $39^{\circ} 26.52^{\prime}$ & $123^{\circ} 18.55^{\prime}$ & $-0.10(112)$ & -0.25 & $0.03(06)$ & $-0.20(149)$ & $-0.18(73)$ & $-0.39(25)$ \\
\hline GBGM & $38^{\circ} 48.84^{\prime}$ & $122^{\circ} 40.76^{\prime}$ & $-0.05(31)$ & 0.20 & $1.54(02)$ & $0.11(23)$ & -0.15 & 0.18 \\
\hline GBMM & $39^{\circ} 08.51^{\prime}$ & $122^{\circ} 29.64^{\prime}$ & $-0.23(43)$ & -0.09 & $-0.16(13)$ & $-0.43(105)$ & $0.30(12)$ & -0.09 \\
\hline GCBM & $39^{\circ} 23.03^{\prime}$ & $123^{\circ} 31.28^{\prime}$ & $-0.07(103)$ & $-0.14(152)$ & $0.12(25)$ & $-0.21(155)$ & $-0.09(75)$ & $-0.24(25)$ \\
\hline GCSM & $39^{\circ} 01.37^{\prime}$ & $123^{\circ} 31.27^{\prime}$ & $0.21(46)$ & $-0.01(11)$ & -0.10 & $0.03(35)$ & $0.11(66)$ & -0.10 \\
\hline GCVM & $38^{\circ} 46.14^{\prime}$ & $123^{\circ} 00.89^{\prime}$ & 0.03 (49) & 0.30 & 0.30 & 0.34 (37) & $-0.05(88)$ & 0.28 \\
\hline GCWM & $39^{\circ} 07.85^{\prime}$ & $123^{\circ} 04.55^{\prime}$ & $-0.12(118)$ & $-0.26(66)$ & $0.05(19)$ & $-0.12(172)$ & $-0.32(100)$ & $-0.21(13)$ \\
\hline GDCM & $38^{\circ} 46.03^{\prime}$ & $123^{\circ} 14.31^{\prime}$ & $0.12(47)$ & 0.15 & 0.15 & $0.40(16)$ & $0.09(100)$ & 0.15 \\
\hline GFRW & $39^{\circ} 37.02^{\prime}$ & $122^{\circ} 25.67^{\prime}$ & $0.83(14)$ & $0.57(11)$ & $0.44(16)$ & $0.47(30)$ & 0.53 & 0.49 \\
\hline GFTM & $38^{\circ} 47.58^{\prime}$ & $122^{\circ} 50.04^{\prime}$ & $-0.25(04)$ & -0.21 & -0.21 & $0.12(02)$ & -0.30 & -0.21 \\
\hline GGLM & $38^{\circ} 53.80^{\prime}$ & $122^{\circ} 46.58^{\prime}$ & $-0.04(50)$ & 0.17 & $0.46(03)$ & $-0.08(48)$ & $0.0(46)$ & 0.21 \\
\hline GGUM & $38^{\circ} 51.39^{\prime}$ & $123^{\circ} 29.87^{\prime}$ & $0.20(36)$ & 0.04 & 0.09 & $0.13(21)$ & $0.11(63)$ & 0.09 \\
\hline GHGM & $39^{\circ} 07.70^{\prime}$ & $122^{\circ} 49.47^{\prime}$ & $-0.12(88)$ & $-0.13(07)$ & $0.01(20)$ & $-0.22(138)$ & $-0.18(80)$ & -0.07 \\
\hline GHLM & $39^{\circ} 02.43^{\prime}$ & $123^{\circ} 01.12^{\prime}$ & $-0.17(107)$ & $-0.11(23)$ & $0.02(20)$ & $-0.18(175)$ & $-0.16(101)$ & -0.22 \\
\hline GHMM & $39^{\circ} 29.74^{\prime}$ & $122^{\circ} 55.80^{\prime}$ & $0.21(109)$ & $0.00(126)$ & $-0.29(35)$ & $-0.06(157)$ & 0.15 (39) & -0.09 \\
\hline GHVM & $39^{\circ} 05.10^{\prime}$ & $122^{\circ} 44.06^{\prime}$ & $-0.03(47)$ & -0.03 & $-0.02(07)$ & $-0.21(72)$ & $-0.01(21)$ & 0.06 \\
\hline GMCM & $38^{\circ} 47.56^{\prime}$ & $123^{\circ} 07.80^{\prime}$ & $-0.08(54)$ & -0.13 & -0.13 & $-0.13(45)$ & $-0.06(102)$ & -0.13 \\
\hline GMKM & $38^{\circ} 58.17^{\prime}$ & $122^{\circ} 47.22^{\prime}$ & $0.11(78)$ & 0.28 & $0.30(11)$ & $0.06(100)$ & $0.17(58)$ & 0.30 \\
\hline GNAM & $39^{\circ} 11.85^{\prime}$ & $123^{\circ} 37.85^{\prime}$ & $0.08(74)$ & $0.18(89)$ & -0.12 & $-0.08(98)$ & $-0.06(85)$ & $-0.17(09)$ \\
\hline GPMM & $38^{\circ} 50.85^{\prime}$ & $122^{\circ} 56.78^{\prime}$ & $-0.02(61)$ & 0.05 & 0.22 & $0.07(61)$ & $0.03(80)$ & 0.07 \\
\hline GRMW & $39^{\circ} 55.03^{\prime}$ & $122^{\circ} 40.17^{\prime}$ & $0.13(29)$ & -0.01 & $-0.05(21)$ & $-0.23(61)$ & -0.02 & $-0.04(16)$ \\
\hline GRNM & $39^{\circ} 10.52^{\prime}$ & $123^{\circ} 34.53^{\prime}$ & $-0.04(14)$ & $0.00(17)$ & 0.76 & $-0.21(20)$ & $-0.09(11)$ & 0.76 \\
\hline GRTM & $38^{\circ} 56.32^{\prime}$ & $122^{\circ} 40.18^{\prime}$ & $-0.26(57)$ & -0.14 & $0.07(09)$ & $-0.34(84)$ & $-0.30(20)$ & -0.14 \\
\hline GSGM & $38^{\circ} 52.03^{\prime}$ & $122^{\circ} 42.58^{\prime}$ & $-0.03(28)$ & 0.26 & 0.18 & $0.02(22)$ & $0.12(16)$ & 0.26 \\
\hline GSNM & $38^{\circ} 56.43^{\prime}$ & $123^{\circ} 11.50^{\prime}$ & $0.06(90)$ & $0.44(05)$ & 0.16 & $0.02(119)$ & $0.01(100)$ & 0.09 \\
\hline GTSM & $39^{\circ} 18.70^{\prime}$ & $122^{\circ} 36.15^{\prime}$ & $0.05(80)$ & $-0.33(21)$ & $-0.25(30)$ & $-0.25(138)$ & $0.19(29)$ & $-0.41(15)$ \\
\hline GWKM & $39^{\circ} 03.12^{\prime}$ & $122^{\circ} 29.46^{\prime}$ & $0.03(32)$ & 0.01 & $0.14(07)$ & $-0.12(51)$ & $-0.01(07)$ & 0.01 \\
\hline GWRM & $39^{\circ} 12.43^{\prime}$ & $123^{\circ} 17.99^{\prime}$ & $0.04(106)$ & $-0.02(81)$ & $0.18(13)$ & $-0.03(144)$ & $-0.20(86)$ & $-0.07(11)$ \\
\hline HAHT & $40^{\circ} 33.53^{\prime}$ & $123^{\circ} 49.57^{\prime}$ & 0.15 & -0.03 & 0.15 & 0.15 & 0.15 & $0.14(63)$ \\
\hline HRST & $40^{\circ} 52.50^{\prime}$ & $123^{\circ} 43.87^{\prime}$ & 0.02 & 0.02 & 0.02 & 0.02 & 0.02 & $-0.06(28)$ \\
\hline KBBM & $40^{\circ} 11.82^{\prime}$ & $123^{\circ} 51.00^{\prime}$ & $0.44(12)$ & $0.26(68)$ & 0.06 & 0.06 & $0.33(08)$ & $0.06(114)$ \\
\hline KBNM & $39^{\circ} 53.56^{\prime}$ & $123^{\circ} 11.64^{\prime}$ & $0.33(48)$ & $0.23(129)$ & $-0.21(31)$ & $-0.07(67)$ & $0.35(06)$ & $0.11(55)$ \\
\hline KBRM & $40^{\circ} 43.79^{\prime}$ & $123^{\circ} 57.34^{\prime}$ & -0.27 & -0.27 & -0.27 & 0.27 & -0.27 & $-0.31(67)$ \\
\hline KBSM & $39^{\circ} 55.07^{\prime}$ & $123^{\circ} 35.68^{\prime}$ & $0.06(44)$ & $-0.13(133)$ & $0.49(11)$ & $0.01(66)$ & $-0.09(16)$ & $-0.10(108)$ \\
\hline KCPM & $39^{\circ} 41.23^{\prime}$ & $123^{\circ} 34.84^{\prime}$ & $0.07(54)$ & $-0.08(124)$ & $0.45(18)$ & $-0.03(106)$ & $-0.08(17)$ & $-0.12(70)$ \\
\hline KCRM & $40^{\circ} 25.58^{\prime}$ & $123^{\circ} 49.11^{\prime}$ & 0.27 & 0.46 & -0.12 & -0.12 & $0.69(04)$ & $-0.04(96)$ \\
\hline KCTM & $40^{\circ} 28.55^{\prime}$ & $124^{\circ} 20.18^{\prime}$ & 0.19 & 0.09 & 0.09 & 0.09 & $0.94(03)$ & $0.05(65)$ \\
\hline KFPM & $39^{\circ} 38.35^{\prime}$ & $123^{\circ} 25.44^{\prime}$ & $-0.17(82)$ & $-0.21(148)$ & $0.11(32)$ & $-0.30(140)$ & $-0.01(31)$ & -0.29 \\
\hline KGMM & $40^{\circ} 45.53^{\prime}$ & $123^{\circ} 40.46^{\prime}$ & 0.13 & 0.13 & 0.13 & 0.13 & 0.13 & $0.08(77)$ \\
\hline KIPM & $39^{\circ} 48.52^{\prime}$ & $123^{\circ} 28.83^{\prime}$ & $-0.13(64)$ & -0.25 & $0.10(26)$ & $-0.26(108)$ & $-0.0(17)$ & $-0.20(83)$ \\
\hline KKPM & $40^{\circ} 08.75^{\prime}$ & $123^{\circ} 28.10^{\prime}$ & $0.40(12)$ & $0.22(85)$ & $0.22(06)$ & $0.22(04)$ & $0.26(06)$ & $0.22(104)$ \\
\hline KMPM & $40^{\circ} 25.04^{\prime}$ & $124^{\circ} 07.21^{\prime}$ & -0.17 & -0.31 & -0.31 & -0.31 & $0.50(06)$ & $-0.33(81)$ \\
\hline KPPM & $40^{\circ} 20.76^{\prime}$ & $123^{\circ} 21.73^{\prime}$ & $0.42(09)$ & $0.24(38)$ & 0.10 & 0.10 & 0.38 & $0.11(86)$ \\
\hline KRKM & $39^{\circ} 33.77^{\prime}$ & $123^{\circ} 10.93^{\prime}$ & $0.09(88)$ & $0.03(126)$ & $-0.12(28)$ & $-0.20(148)$ & $0.13(35)$ & $-0.03(43)$ \\
\hline KSMM & $40^{\circ} 11.15^{\prime}$ & $124^{\circ} 10.48^{\prime}$ & $0.25(04)$ & $0.19(20)$ & -0.40 & -0.40 & $-0.88(05)$ & $-0.43(31)$ \\
\hline KSPM & $39^{\circ} 31.04^{\prime}$ & $123^{\circ} 30.09^{\prime}$ & $-0.02(96)$ & 0.02 (147) & $0.22(26)$ & $-0.14(146)$ & $-0.19(45)$ & $-0.03(34)$ \\
\hline MMRT & $40^{\circ} 25.35^{\prime}$ & $124^{\circ} 05.78^{\prime}$ & 0.05 & 0.05 & -0.29 & -0.29 & -0.05 & $-0.32(62)$ \\
\hline MVRT & $40^{\circ} 40.53^{\prime}$ & $123^{\circ} 51.70^{\prime}$ & -0.22 & -0.22 & -0.22 & -0.22 & -0.22 & $-0.25(71)$ \\
\hline NMTM & $38^{\circ} 48.34^{\prime}$ & $122^{\circ} 26.76^{\prime}$ & $-0.13(35)$ & -0.12 & 0.00 & $-0.08(40)$ & $0.16(17)$ & 0.0 \\
\hline PRTT & $40^{\circ} 07.23^{\prime}$ & $123^{\circ} 41.50^{\prime}$ & 0.24 & 0.29 & 0.28 & $0.02(03)$ & $0.37(03)$ & $0.28(73)$ \\
\hline WHTT & $40^{\circ} 01.00^{\prime}$ & $123^{\circ} 56.25^{\prime}$ & $-0.13(03)$ & -0.24 & -0.17 & -0.17 & $-0.26(03)$ & $-0.19(73)$ \\
\hline WR2T & $40^{\circ} 23.21^{\prime}$ & $124^{\circ} 17.44^{\prime}$ & -0.20 & -0.20 & -0.20 & -0.20 & -0.35 & -0.24 \\
\hline
\end{tabular}

The number in parentheses is the number of readings used to determine the station delay. Delays without a number indicate the readings were less than 4 .

right-lateral on dipping fault planes. Although several events display a small component of oblique-reverse slip, strike-slip motion predominates. For most events, at least one of the nodal planes is consistent with a structure that dips $50^{\circ}$ to $75^{\circ}$ to the northeast (Figures 7 and 8).
A longitudinal cross-section of seismicity along the Maacama fault is illustrated in profile B in Figure 8. Earthquakes locate as deep as $12-15 \mathrm{~km}$ depth near the towns of Laytonville and Willits, and shallow to about $7 \mathrm{~km}$ near Clear Lake. Most of the earthquakes locate near the base of the seis- 


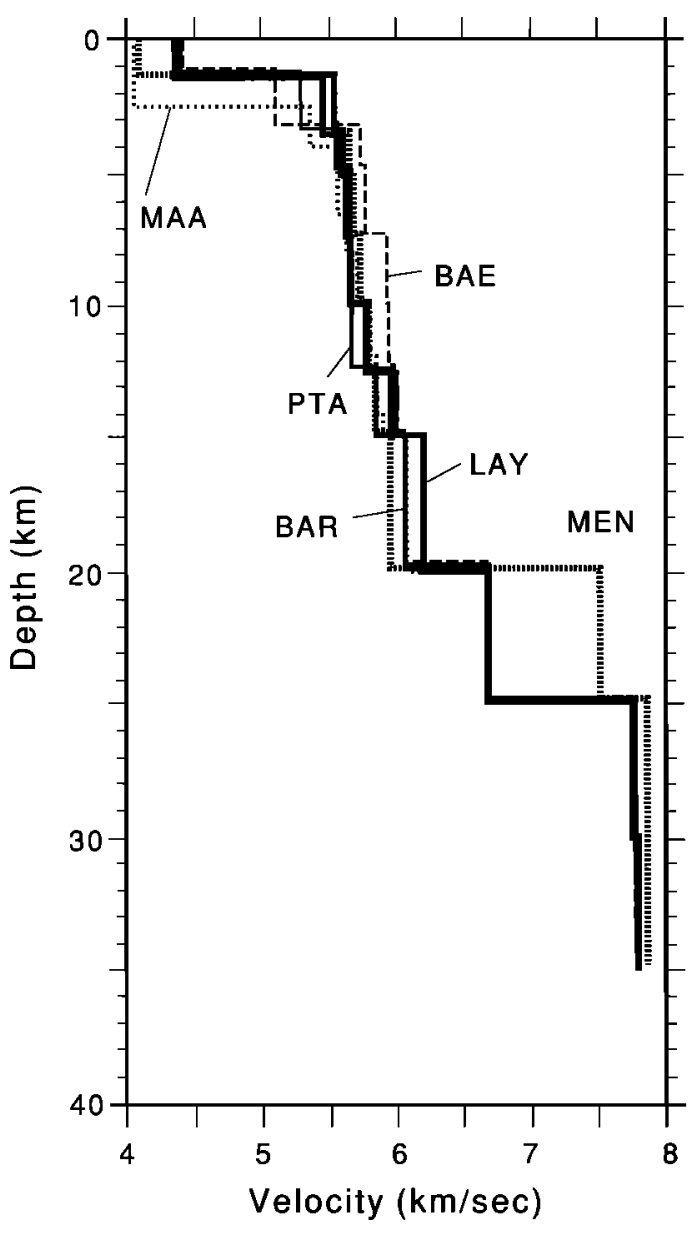

Fig. 3. Velocity models developed for this study.

mogenic zone with sparse activity in the shallow sections $(<8 \mathrm{~km})$ indicating that either the shallower sections are locked or are slipping aseismically. Aseismic slip occurs at Willits, where curb offsets have been observed [Pampeyan et al., 1981; Upp, 1982]. Microseismicity at the northern end of the Maacama fault terminates near the southern edge of the Gorda slab, while the Garberville fault located immediately north of the Maacama shows relatively little seismicity within the North American plate if we adopt the Jachens and Griscom [1983] interpretation for the top of the Gorda slab (Figure 4 and profile $B$ in Figure 8).

To test the reliability of a northeast dipping nodal plane, we subjected the focal mechanisms shown in Figure 5 to additional tests. We constrained one nodal plane to be vertical but allowed the strike of this nodal plane to vary between $\mathrm{N} 15^{\circ}-35^{\circ} \mathrm{W}$ (strike range of the Maacama fault), but left the rake unconstrained. For earthquakes 1, 6, 11, 12, 27, 41,48 , and 53 (Figure 5), the misfit at the $90 \%$ confidence level for the constrained solution was greater than a misfit for the unconstrained solution, indicating that these earthquakes indeed have a northeast dipping fault plane (Figure 9). In contrast, earthquakes 4 and 29 can be fit equally well by either a dipping or vertical fault plane.

The northeast dip of the Maacama fault zone steepens from north to south. Near its northern terminus, there are two distinct subparallel faults that project to the surface traces of the Maacama fault zone (profiles $F$ and $G$ in Figure
9). In profile $F$ the most seismically active fault strand dips about $60^{\circ}$ while the other less pronounced fault strand dips about $50^{\circ}$. The $50^{\circ}$ dipping structure is also apparent in profile $G$, whereas the seismicity associated with the $60^{\circ}$ dipping fault becomes diffuse at about $10 \mathrm{~km}$ depth. The $50^{\circ}$ and $60^{\circ}$ double fault zone geometry in the north coalesces to a single fault structure dipping at about $70^{\circ}$ to the northeast in profile $\mathbf{H}$ (Figure 9). This segment of the Maacama fault near Willits includes the November 21, 1977, M4.9 Willits earthquake (profile $B$ in Figure 8 and profile $H$ in Figure 9) [Simon et al., 1978; Warren et al., 1985]. The focal mechanism associated with the Willits earthquake shows it to be pure right-lateral strike-slip along a structure dipping $\sim 80^{\circ}$ to the northeast (Figures 8 and 9). In profiles $I, J$, and $K$ of Figure 9, diffuse seismicity along the Maacama fault zone concentrates between depths of 5-10 km, making it difficult to identify a particular fault trace. South of Clear Lake, where the southern end of the Maacama steps to the west to join with the Healdsburg fault, the seismicity is also diffuse and is interpreted to consist of a series of multiple fault strands [Wong, 1990].

Unusually deep earthquakes were also observed near the west shores of Clear Lake (profiles A and B in Figure 8). These earthquakes occur down to $25 \mathrm{~km}$ in depth with magnitudes that fall within the 1.0-2.0 range and have an unusual longperiod character to their waveforms (S. Walter, USGS, oral communication, 1991). Walter and Dzurisin [1989] have observed similar long-period earthquakes to occur in the $25 \mathrm{~km}$ depth range immediately below the Medicine Lake and the Lassen Peak volcanos (S. Walter, USGS, personal communication, 1991). This suggests a volcanic association, comparable to the magmatic processes currently active under relatively youthful volcanic edifices such as the Medicine Lake and Lassen Peak volcanos. Similar long-period earthquakes located at depths $>25 \mathrm{~km}$ have been observed in the northeastern Japan arc [Hasegawa et al., 1991].

The dominate north-northeast orientation of the $P$ axes associated with earthquakes located along the Maacama fault indicates that the fault is primarily responding to right-lateral shear strain induced by Pacific-North American plate motion (Figure 6). This pattern of right-lateral strain persist along the entire length of the fault, despite the fact that the ruptured planes are not vertical but dip to the northeast. Earthquakes located north of Point Arena and between the Maacama and San Andreas faults, typically demonstrate right-lateral shear strains (e.g., earthquakes 47, 51, and 55 in Figure 5) with north-northeast trending $P$ axes (Figure 6), suggesting that distributed shear strains in this area maybe accommodated along multiple fault strands.

At its northern end, seismicity associated with the Maacama fault terminates abruptly near the town of Laytonville, above the inferred southern edge of the Gorda slab. Earthquake $P$ axes for earthquakes fall into two groups: a northnortheast trend consistent with right-lateral slip along northeast dipping faults (e.g., earthquake 12, 40, and 44), and a northeast trend which is nearly perpendicular to the Maacama fault (e.g., earthquake 24) related to both strike-slip and oblique reverse slip along more westerly striking nodal planes (Figures 5 and 6).

An off-fault trend of earthquakes occurs between Clear Lake and Point Arena, along a $25 \times 10 \mathrm{~km}$ long westnorthwest trending zone with hypocentral depths restricted to the upper $10 \mathrm{~km}$ depth (Figures 4 and 5 , profile $\mathrm{K}$ in Figure 


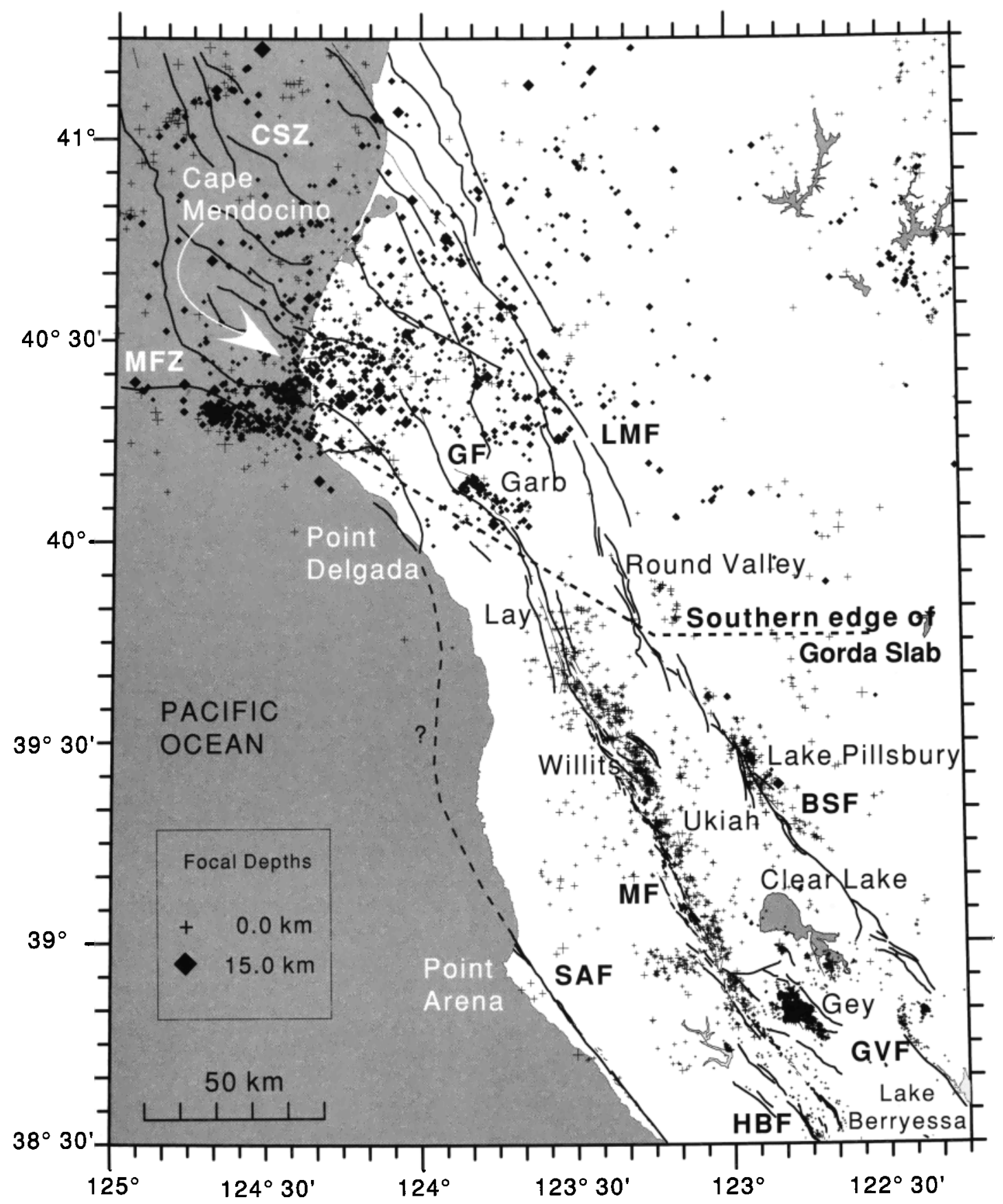

Fig. 4. Seismicity of northern California for the 1980-1991 time period after relocation with regionalized crustal velocity models (Tables 1 and 2). Data considered in this study did not include earthquakes along the Healdsburg fault or the events in The Geysers area. All events of $M>1.5$ (duration magnitudes), rms $\leq 0.15 \mathrm{~s}$, standard horizontal error $\leq 1.0 \mathrm{~km}$, and standard vertical error $\leq 2.5 \mathrm{~km}$ are shown. Earthquakes shallower than $15 \mathrm{~km}$ are plotted as crosses, and events deeper than $15 \mathrm{~km}$ are plotted as solid diamonds. The dashed line is the surface projection of the southern edge of the Gorda slab after Jachens and Griscom [1983]. CSZ, Cascadia subduction zone; BSF, Bartlett Springs fault; Garb, Garberville; GF, Garberville fault; Gey, Geysers; GVF, Green Valley fault; HBF, Healdsburg fault; Lay, Laytonville; LMF, Lake Mountain fault; MF, Maacama fault; MFZ, Mendocino fracture zone; and SAF, San Andreas fault.

9). This seismicity occurs slightly west (near $123^{\circ} 10^{\prime} \mathrm{W}$ in Figures 4 and 5) of an apparent right-step along the Maacama fault [Herd and Helley, 1977]. Although no active fault has been mapped, geologic evidence indicates a transition from the Coastal belt Franciscan Complex and the central Franciscan melange belt occurs close to this region [Jennings et al., 1977]. Focal mechanisms generally show right-lateral motion on northwest trending nodal planes; however, the dip of the apparent fault plane varies from steep (earthquakes 45 and 58) to very shallow (earthquakes 25 and 43 ).

\section{Bartlett Springs Fault Zone}

The Bartlett Springs fault is observed over a distance of $100 \mathrm{~km}$ between latitudes $39^{\circ} 50^{\prime} \mathrm{N}$ and $39^{\circ} \mathrm{N}$, and may link up 


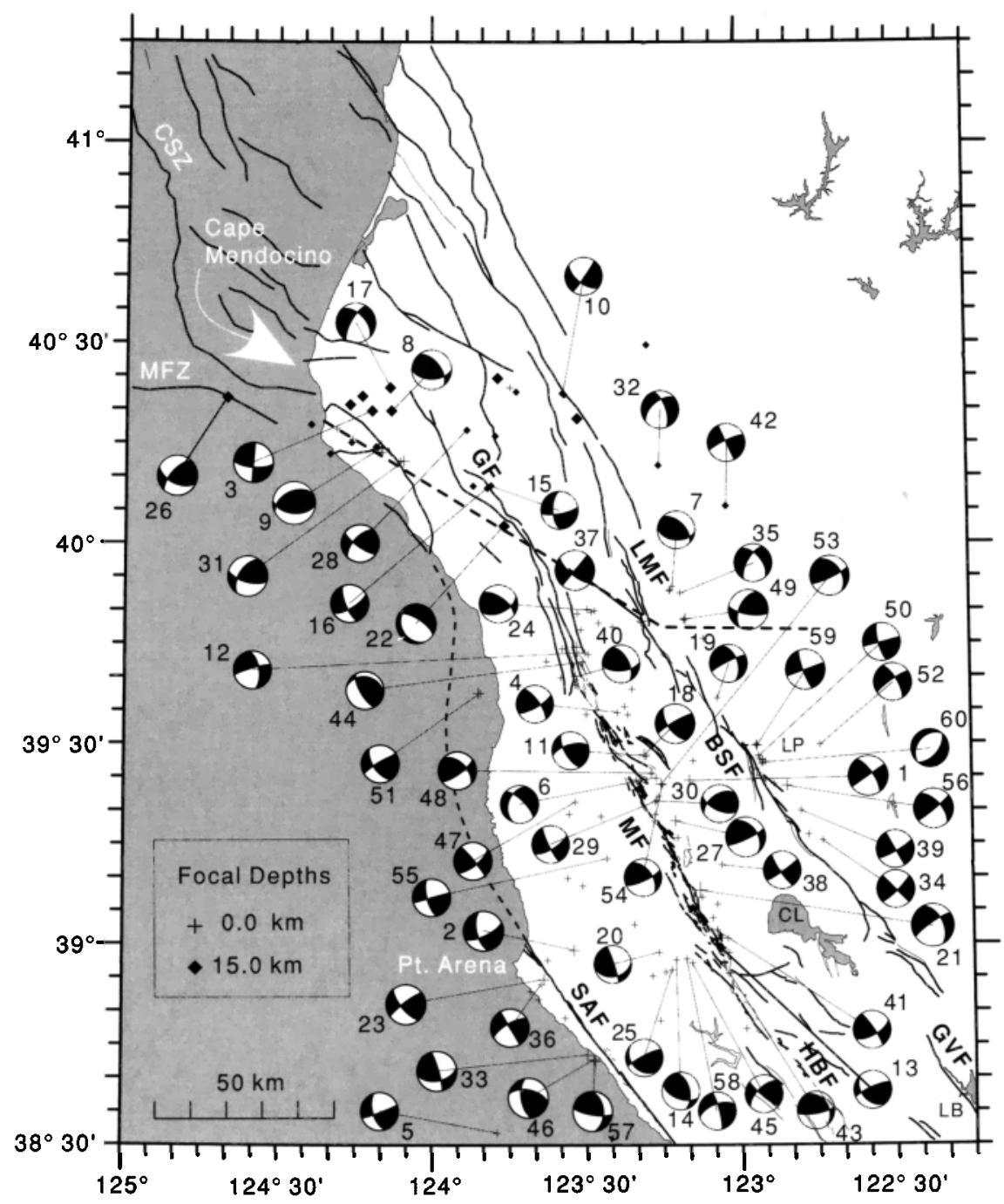

Fig. 5. Representative earthquake focal mechanisms for events $M>2$. Focal sphere is lower hemisphere projection with compressional quadrant shaded. Each focal mechanism used in this figure is indexed in Figure 10 and listed in Table 3 . All the earthquakes shown, including those not represented by their respective mechanisms, were used in plotting $P$ and $T$ axes in Figure 6. Abbreviations same as in Figure 4.

with the Green Valley fault near San Francisco (Figures 1, 2, and 4) [Dehlinger and Bolt, 1984; Hill et al., 1990; Wong, 1990]. The surface trace of the Bartlett Springs lacks largescale, fault-generated morphology typical of mature strikeslip faults (e.g., pressure ridges and offset channels). One exception is at Lake Pillsbury, where the fault steps slightly to the east, forming a small pull-apart basin (Figure 4).

Earthquake focal mechanisms along the Bartlett Springs fault are primarily right-lateral strike-slip, with northwest trending and northeast dipping nodal planes (Figures 4 and 5). The similarity between the style of faulting seen along the Maacama and the Bartlett Springs faults indicates that the region as a whole accommodates Pacific-North American plate motion (Figure 4). Near Round Valley, however, $P$ axes deviate from the dominate north-northeast trend to become nearly parallel to the Bartlett Springs and Lake Mountain faults (earthquakes 35 and 49 in Figure 5; and Figure 6). The seismicity east of Round Valley (Figure 4, cross-section distance $\mathbf{7 0 - 8 0} \mathrm{km}$ in profile A of Figure 8, and distance $70 \mathrm{~km}$ in profile $\mathrm{F}$ of Figure 9) appears to define an unmapped fault, parallel to the Lake Mountain and Bartlett Springs fault zones.

Compared to the Maacama fault, the seismicity along the Bartlett Springs is quite discontinuous along strike, with earthquakes tending to concentrate in clusters (Figure 4 and profile $A$ in Figure 8 ). Furthermore, the base of the seismogenic zone along Bartlett Springs fault occurs within the $15-18 \mathrm{~km}$ depth range (profile $A$ in Figure 9), significantly deeper than observed along the Maacama fault (profile B in Figure 9). Just as with the Maacama, the northern terminus of the Bartlett Springs fault coincides with the southern edge of subducting Gorda plate. To the north, essentially no shallow $(<20 \mathrm{~km})$ microseismicity occurs along the Lake Mountain fault (Figure 4 and profile $A$ in Figure 8).

Seismicity along the Bartlett Springs fault is essentially absent between Lake Pillsbury and Round Valley. The vertical column of earthquakes located at distance $105 \mathrm{~km}$ in profile A of Figure 8 and distance $70 \mathrm{~km}$ profile $\mathrm{G}$ of Figure 9 is an artifact of poor depth resolution in a region of sparse network coverage (Figure 2). Farther south, in the Lake 

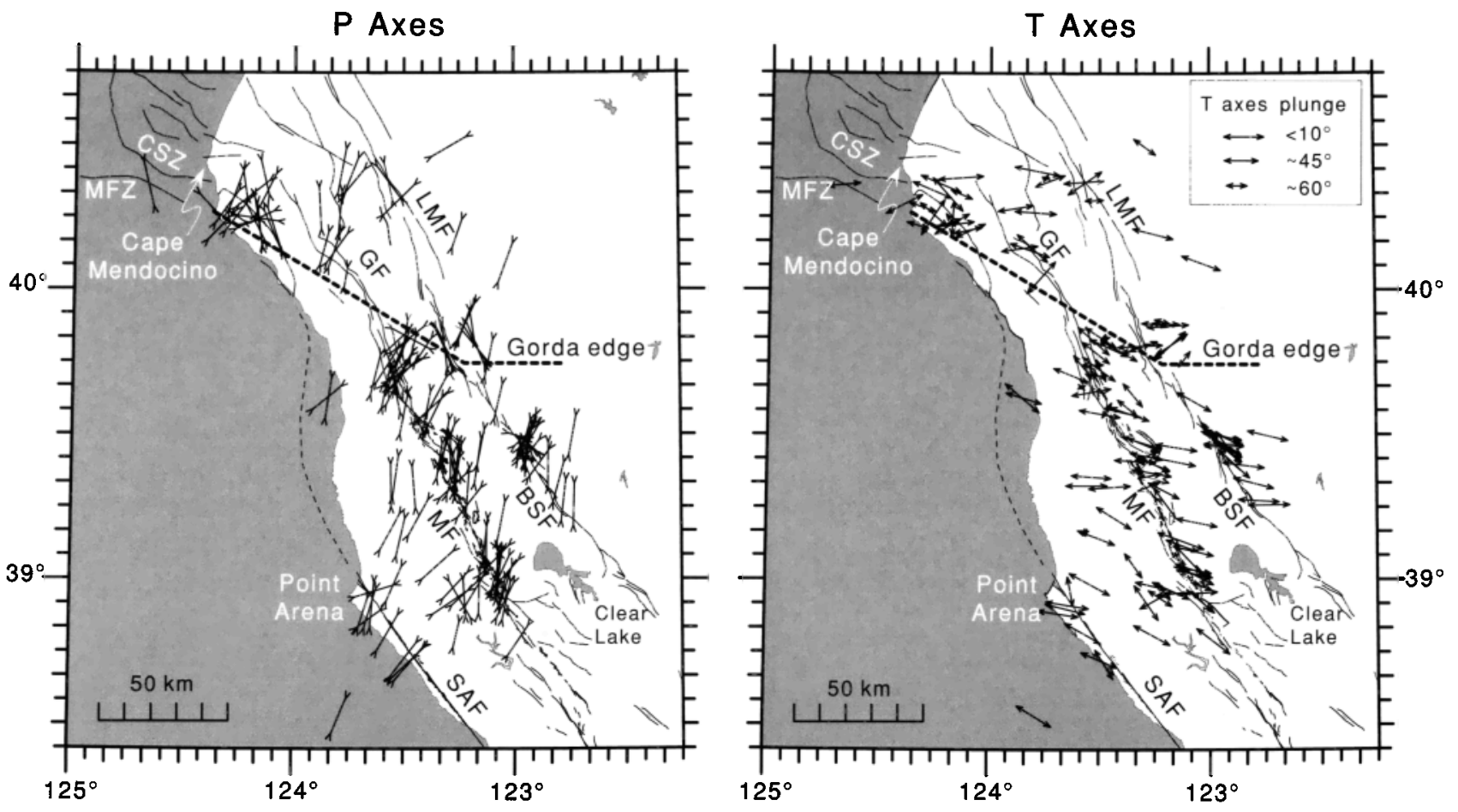

Fig. 6. $P$ and $T$ axes from all the earthquakes $(M>2)$ shown in Figure 5. The bold dashed line is the surface projection of the southern edge of the Gorda slab. The slightly east of north orientation along the Maacama and Bartlett Springs fault zones is consistent with regional right-lateral strain release on these northwest trending fault planes. The insert in the $T$ axes plot is a guide for judging the plunge of the axes.

a)

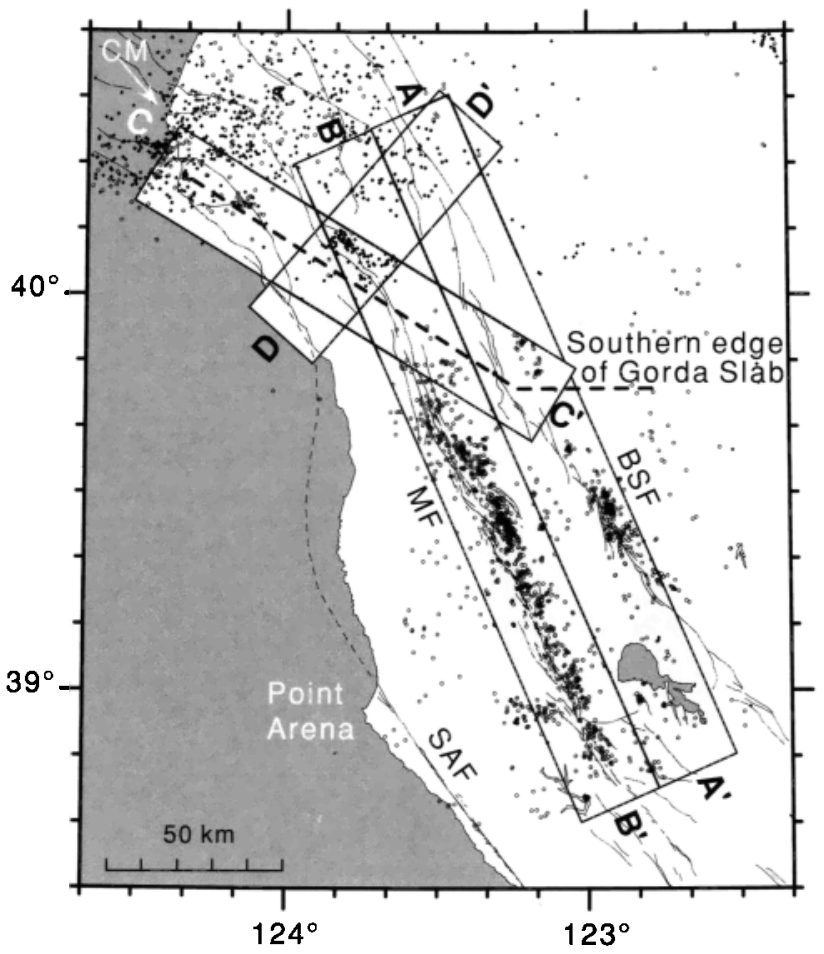

b)

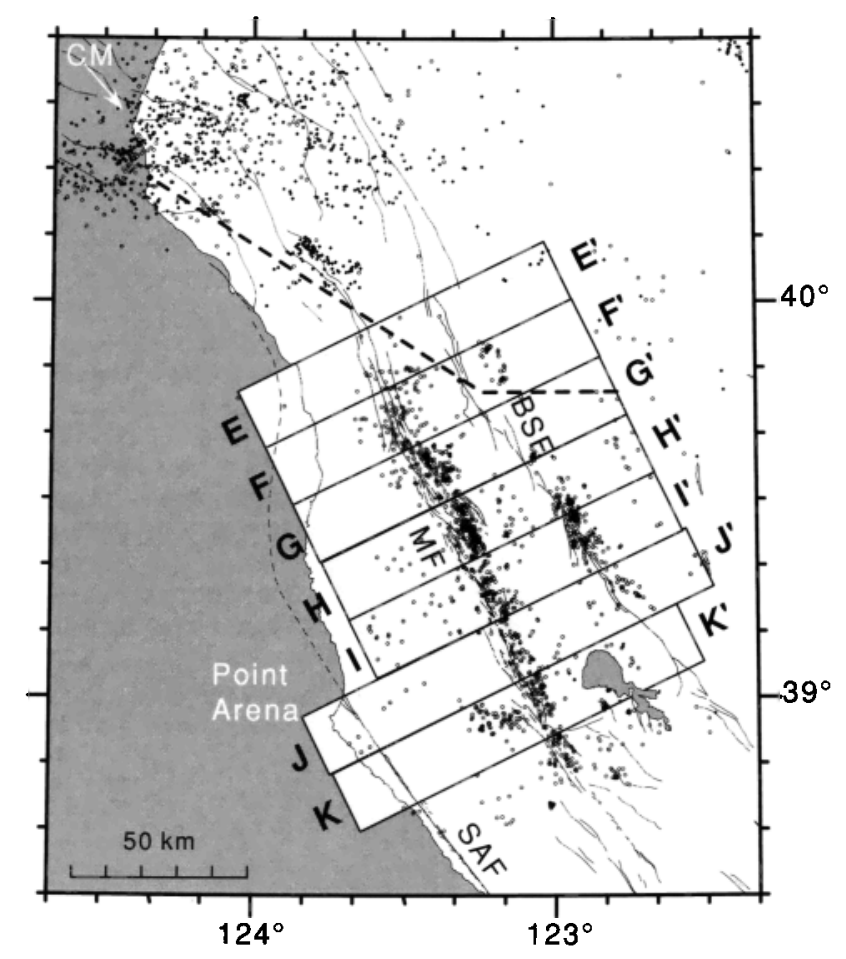

Fig. 7. (a) Location map for seismic cross-sections in Figure 8, where each cross section covers a 30-km-wide region. (b) Location map for seismic cross sections in Figure 9, where each cross section covers an 18-km-wide region. 
a)

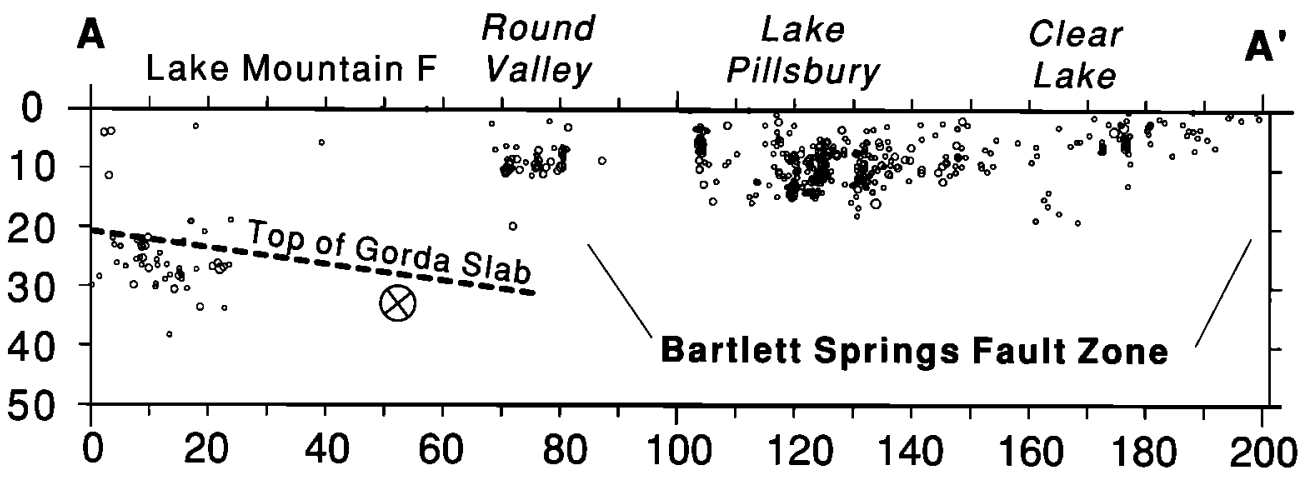

b)
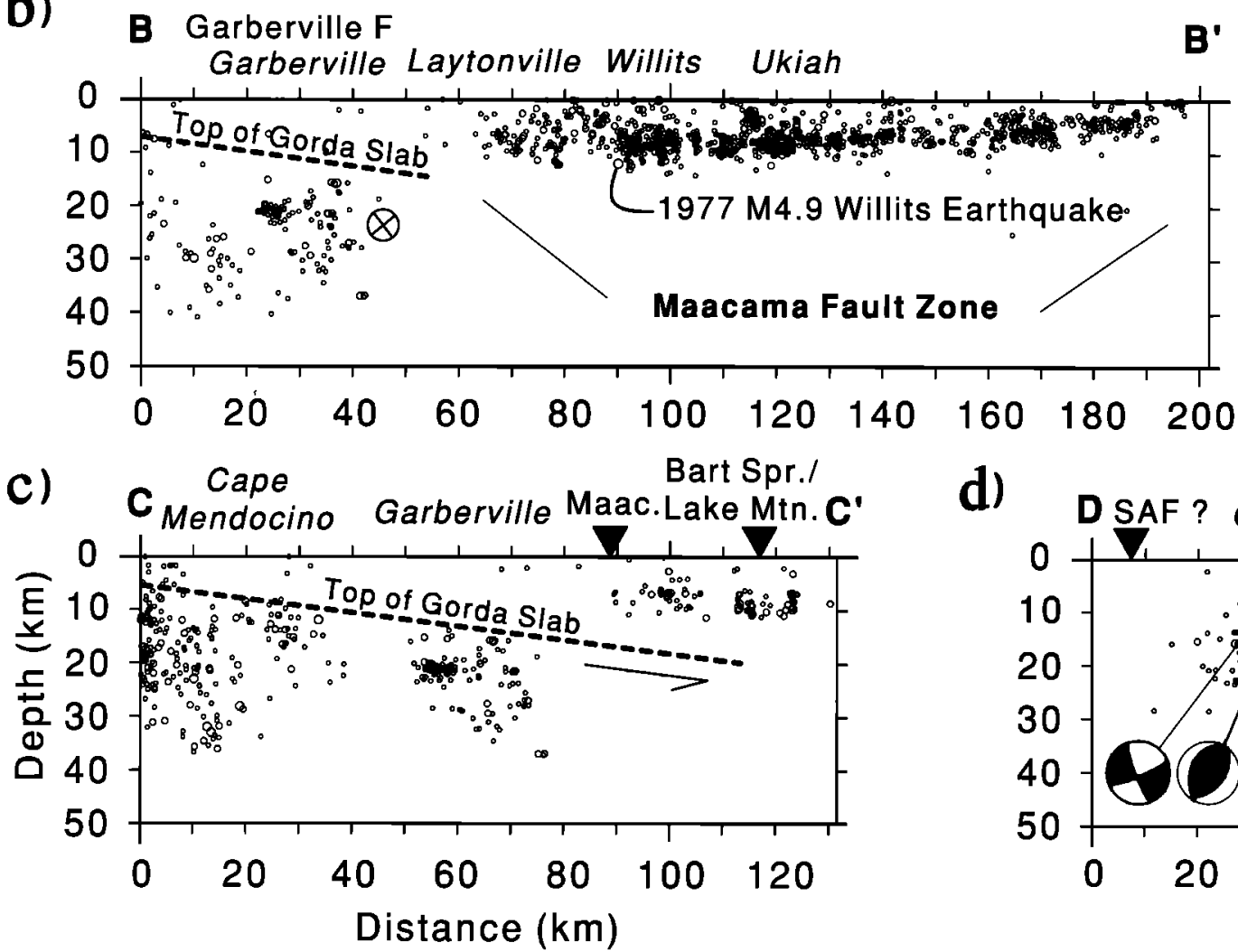

d)

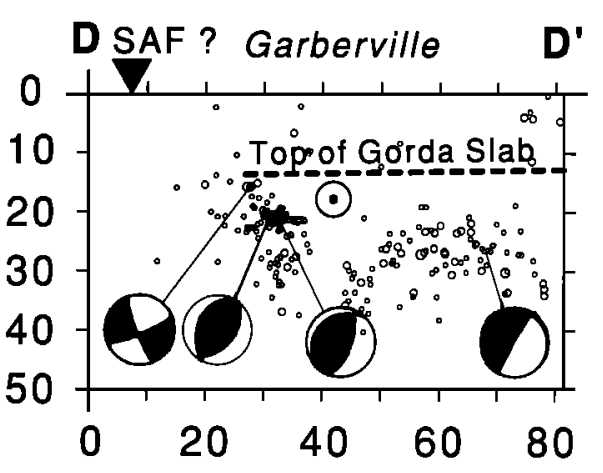

Fig. 8. (a) Cross section A-A' showing seismicity along the Bartlett Springs fault and northwestward to include the southern edge of the Gorda slab. The dashed line corresponds to the top of the Gorda slab after Jachens and Griscom [1983], and the arrowhead and tail depict relative motion with respect to the North American plate. Geographic locations are labeled with italics. (b) Cross section B-B' showing seismicity along the Maacama fault and northwestward to include the southern edge of the Gorda slab. Shown is the location of the November 21, 1977, M4.9 Willits Earthquake. $(c)$ Downdip cross section C-C' of the southern edge of the Gorda slab from Cape Mendocino and the northern terminus of the Maacama and Bartlett Springs faults. (d) Cross section D-D' of the Gorda slab showing earthquakes beneath the Gorda slab in the Garberville area. Focal mechanisms (from left to right are 22, 16, 15, and 10) in $D_{-} \mathrm{D}^{\prime}$ are projected onto the plane of the section. Inverted triangles are surface traces of indicated faults. Note the abrupt change from the deep (>15 km depths) focal depths at distance $45 \mathrm{~km}$ in B-B' corresponding to the Gorda slab, to the shallower $(<15 \mathrm{~km}$ depths) associated with the Maacama fault. The deep $(\geq 20 \mathrm{~km})$ events located between 160 and $170 \mathrm{~km}$ in $\mathbf{A}-\mathbf{A}^{\prime}$ are long-period events presumably associated with remnant magma sources associated with the Clear Lake volcanic rocks (S. Walters, USGS, personnel communication, 1990). The shallowing of the base of the seismogenic zone along the Maacama fault $(\sim 12 \mathrm{~km}$ depth near Laytonville to $\sim 8 \mathrm{~km}$ depth near Clear Lake) is consistent with the warming effects due to the opening of the asthenospheric "window" immediately south of the southern edge of the Gorda slab.

Pillsbury area along profiles $H$ and $I$ in Figure 9, the Bartlett Springs fault dips about $65^{\circ}-70^{\circ}$ to the northeast. North of Clear Lake, the northeast dip of the Bartlett Springs fault is moderately defined in the seismic data, but farther south, the fault essentially becomes aseismic (Figure 7 and profiles J and $\mathrm{K}$ in Figure 9).

The uniqueness of a northeast dipping fault along the Bartlett Springs fault was tested using the same geometric 

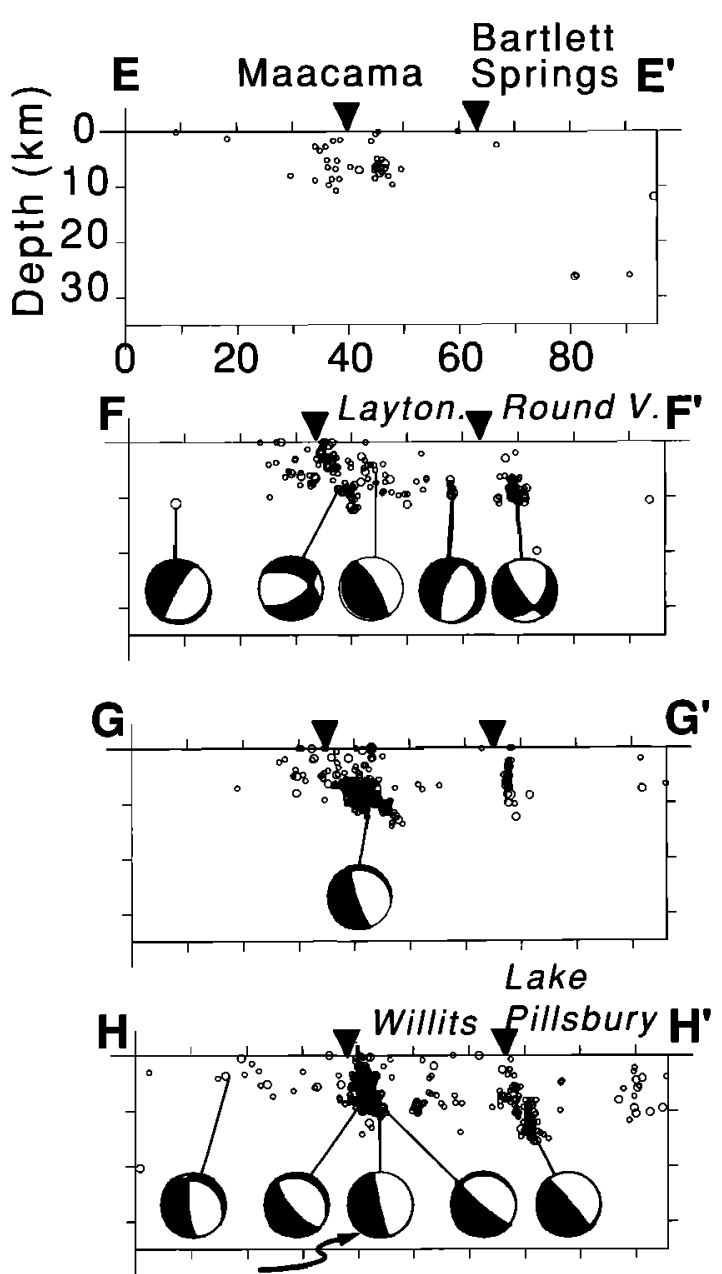

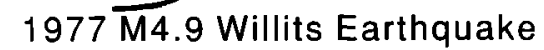
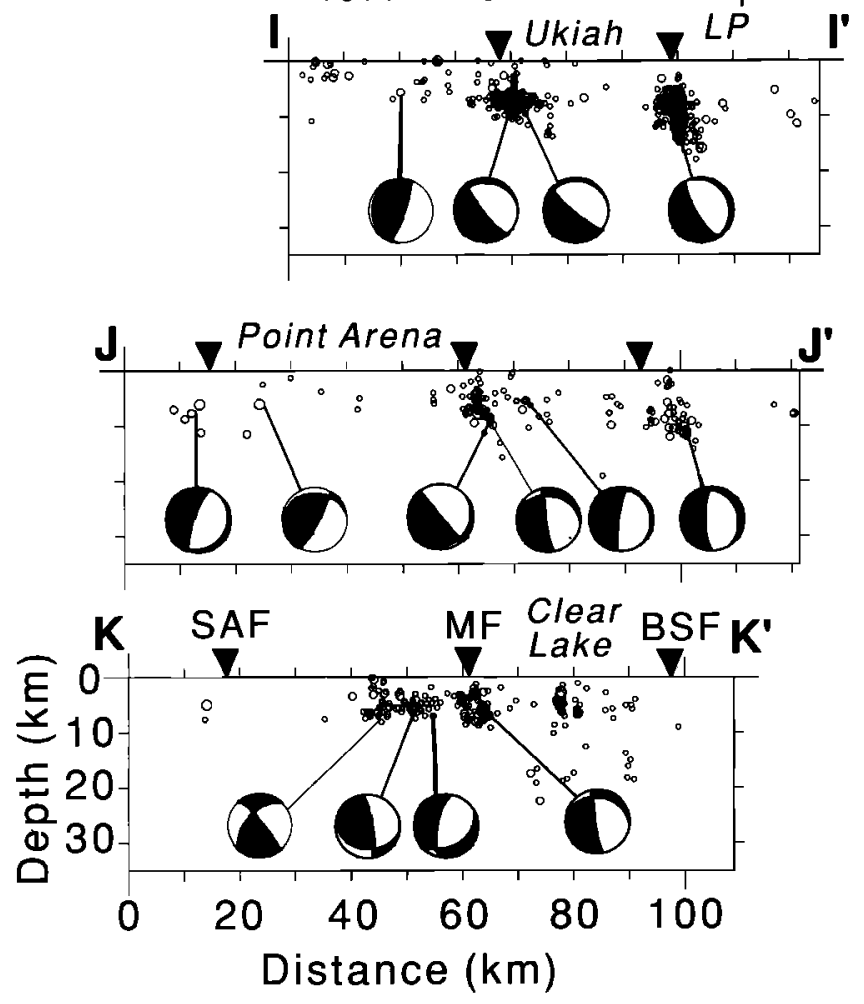

constraints as applied to Maacama fault earthquakes. The results indicate that a vertical fault plane solution is rejected by earthquakes 19 and 56 (Figure 5). Because earthquakes 34,39 , and 59 are best explained with a near-vertical fault and since the seismic network coverage east of the Bartlett Springs fault is relatively sparse (Figure 2), we cannot entirely rule out the possibility of a vertical Bartlett Springs fault with the available data.

\section{Cape Mendocino}

North of Cape Mendocino, Wadati-Benioff zone seismicity defines the southeast dipping Gorda slab to be at a depth of 20-25 km near the coastline [McPherson, 1989; Hill et al., 1990]. It steadily deepens eastwards to a maximum depth of 80-90 km depth beneath north central California Lassen Peak [Cockerham, 1984; Walter, 1986; Dewey et al., 1989]. Where the slab is juxtaposed against the Mendocino fracture zone, earthquakes occur along a vertical $5-10 \mathrm{~km}$ wide zone which parallels the Mendocino fracture zone and extends to about $35 \mathrm{~km}$ depth (profile $\mathrm{C}$ in Figure 8) [McPherson, 1989; Hill et al., 1990]. Seismic refraction and crustal velocity inversion experiments [Knapp et al., 1978; Smith and Knapp, 1980], and gravity and magnetic data [Silver, 1971; Jachens and Griscom, 1983]. Jachens and Griscom [1983] indicate that the Gorda slab is dipping $9^{\circ}-11^{\circ}$ to the southeast.

Seismicity near Garberville, located $50-70 \mathrm{~km}$ southeast of Cape Mendocino, occurs at hypocentral depths that range from 10 to $35 \mathrm{~km}$ deep (Figures 4 and 7 and profile $D$ in Figure 8). The focal depths of these events imply that they are not associated with the Garberville fault (near the town of Garberville). Focal mechanisms for the deep Garberville events indicate right-lateral slip along northwest planes (earthquakes 15 and 16), as well as normal faulting along planes that subparallel the southern edge of the Gorda slab (earthquake 22 in Figure 5). Clarke [1992] interprets the Garberville fault as part of the Coastal Franciscan suture thrust fault active during Eocene and Oligocene time.

Earthquakes in the Mendocino area (Figure 4) can be separated into two classes based on depth and $P$ and $T$ axes (Figures 5 and 6). Earthquakes occurring at depths $>15 \mathrm{~km}$ (earthquakes $3,8,15,16$, and 32) are associated with northeast trending $P$ axes and $T$ axes that plunge between $10^{\circ}$ and $60^{\circ}$ in a direction subparallel to the southern edge of the Gorda slab (Figures 5 and 6). We interpret these deeper events with southeast plunging $T$ axes to indicate downdip tension within the Gorda slab. The reverse to obliquereverse earthquakes occurring at depths $<15 \mathrm{~km}$ (earth-

Fig. 9. (Opposite) Transverse cross sections (E-K) crossing the Maacama, Bartlett Springs, and San Andreas fault zones. Geographic locations are labeled with italics. Inverted triangles are surface traces of indicated faults. Focal mechanisms are projected onto the cross sections. The projection corresponds to the hemisphere furthest from the viewer, such that for a pure right-lateral strike-slip earthquake, viewing to the northwest along the plane of the fault, the shaded compressional quadrant would occur on the left side. The number of each mechanism for the profiles from left to right are: profile $F, 51,12,40,19$, and 35 ; profile $G, 4$; profile $H, 47$, 48, November 21, 1977 M4.9 Willits Earthquake, 53, and 33; profile $\mathrm{I}, 55,54,27$, and 56; profile $\mathrm{J}, 23,2,21,38$, and 34 ; profile $\mathrm{K}, 14,58$, 45 , and 41. Note the northeast dip of the Maacama fault zone in sections $F, G$, and $H$. 


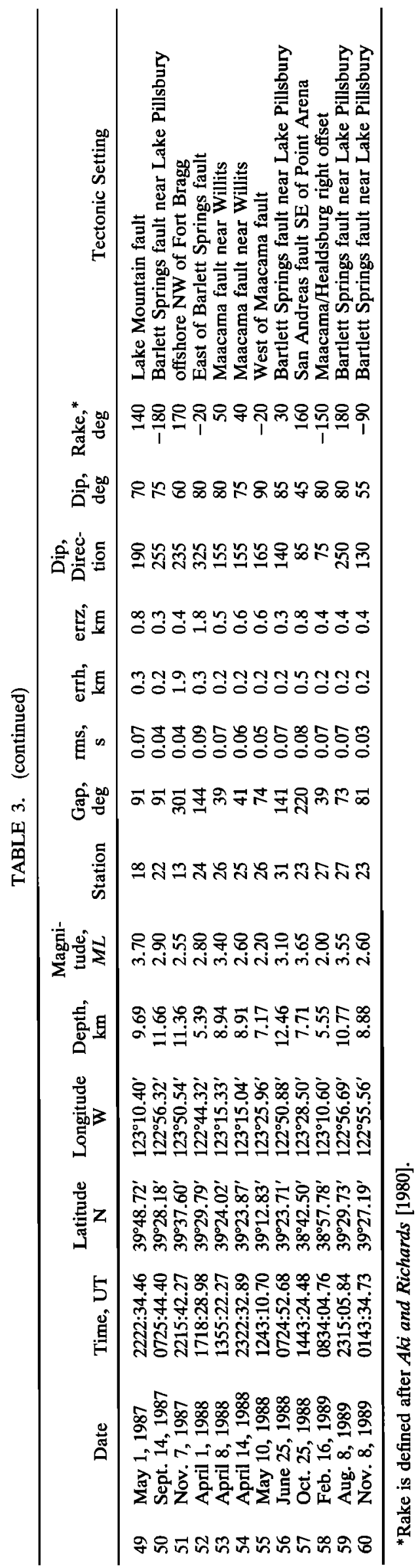

quakes 9 and 31) have northwest oriented $P$ axes and subhorizontal $T$ axes and are located near the intersection of the San Andreas fault with both the southern edge of the Gorda slab and the eastern end of the Mendocino Fracture Zone (Figures 5 and 6).

\section{Development and Evolution of THE Northern San ANDreas Fault System}

The Pacific-North America plate boundary lengthens at a rate of about $5 \mathrm{~cm} / \mathrm{yr}$ in the wake of the northward migrating Mendocino triple Junction [Atwater and Molnar, 1973; Atwater, 1989]. When the triple junction passes, subduction processes beneath the North American plate cease, and the Pacific-North American plate boundary lengthens. In lengthening, it inherits a compressional tectonic fabric originally formed within the Cascadia forearc region. This fabric is made up of low- to high-angle reverse faults and compressional folds whose axes parallel the trend of the reverse faults which are currently active to the east and northeast of Cape Mendocino (Figures 1 and 4). Generally, these reverse faults dip to the northeast as do most of the regional structures in the offshore areas [Kelsey and Carver, 1988; Clarke, 1992]. Based on heat flow [Lachenbruch and Sass, 1980], gravity [Jachens and Griscom, 1983], and seismicity data (this study), the southern edge of the Gorda slab appears to delineate a boundary between two tectonic provinces: convergent processes active within the forearc region and transform processes associated with the San Andreas fault system.

Based on similar fault strike/dip geometries between the Garberville-Maacama and Lake Mountain-Bartlett Springs fault pairs [Pampeyan et al., 1981; Kelsey and Carver, 1988] and seismicity along the Maacama and Bartlett Springs faults, we suggest that transform slip along the northern end of the San Andreas fault system initiates along preexisting structures, such as the Garberville and Lake Mountain faults (Figures 1 and 4), that once accommodated Gorda-North American plate convergence.

The location of the southern edge of the Gorda slab (Figures 4 and 8) appears to play an important role in controlling the onset of transform motion along the inboard members of the San Andreas fault system. The elastic thickness of the combined Gorda and North American plates may be as much as twice the thickness of the North American plate south of the southern edge of the Gorda slab. This abrupt decrease in the elastic thickness of the lithosphere occurs when the Mendocino triple junction migrates northward leaving behind a section of the North American plate detached from the underlying Gorda slab and exposing the plate to the upwelling asthenospheric material [Dickinson and Synder, 1979; Lachenbruch and Sass, 1980; Furlong et al., 1989]. This abrupt reduction in the plate thickness could concentrate shear stresses, permitting failure along the most optimally oriented faults. In our study area, we suggest that the optimal faults would be the southern extrapolation of the Garberville fault (Maacama fault south of the Gorda edge) and the Lake Mountain fault (Bartlett Springs fault south of the Gorda edge), faults that had previously existed as reverse faults in the Cascadia forearc area.

If North American-Pacific plate motion continues north of the Gorda edge, strong coupling along the Gorda and North American plate interface could inhibit transform motion. 

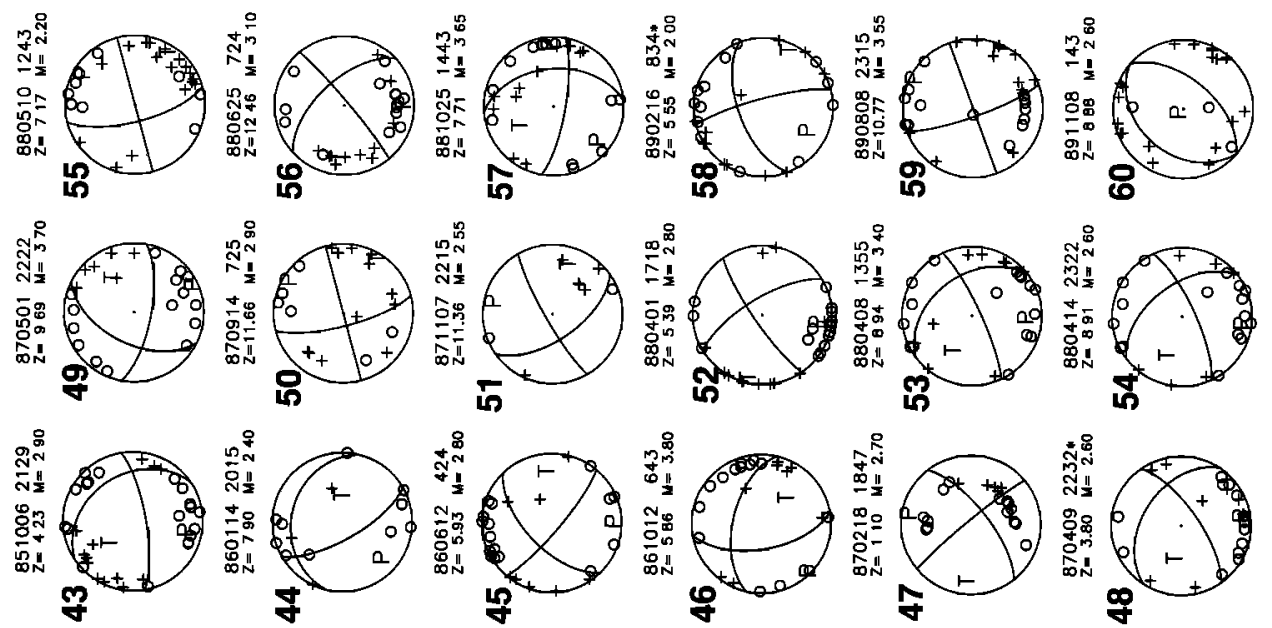

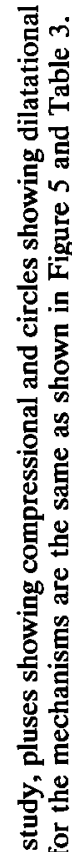
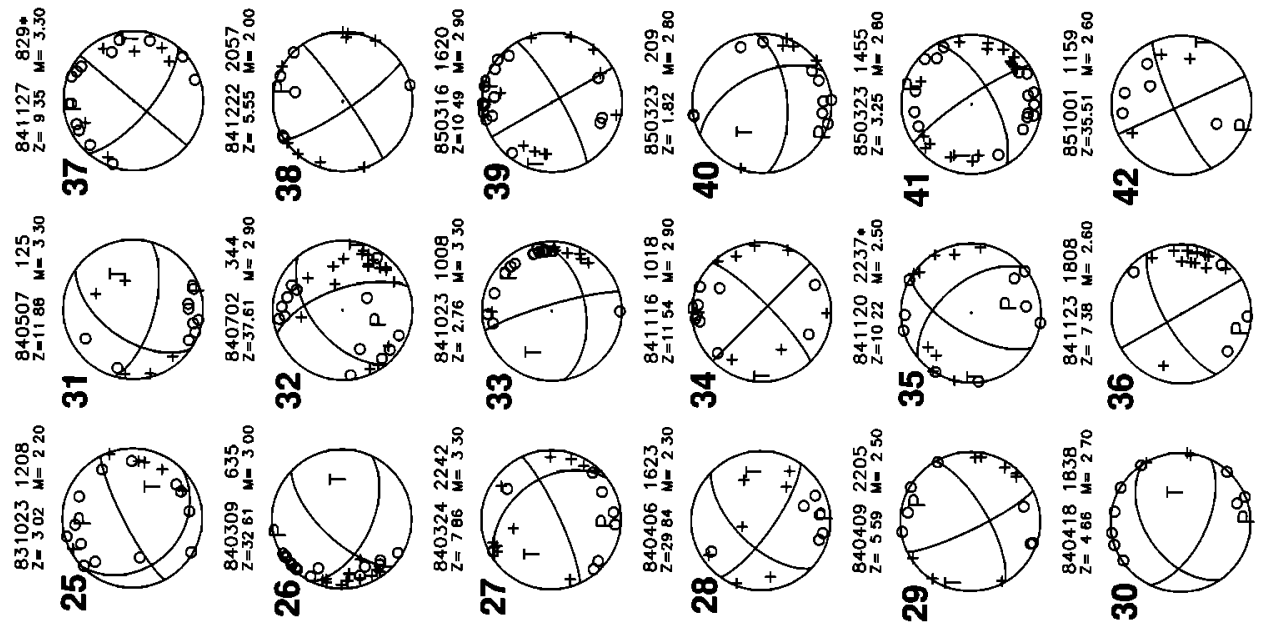

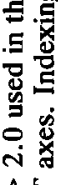
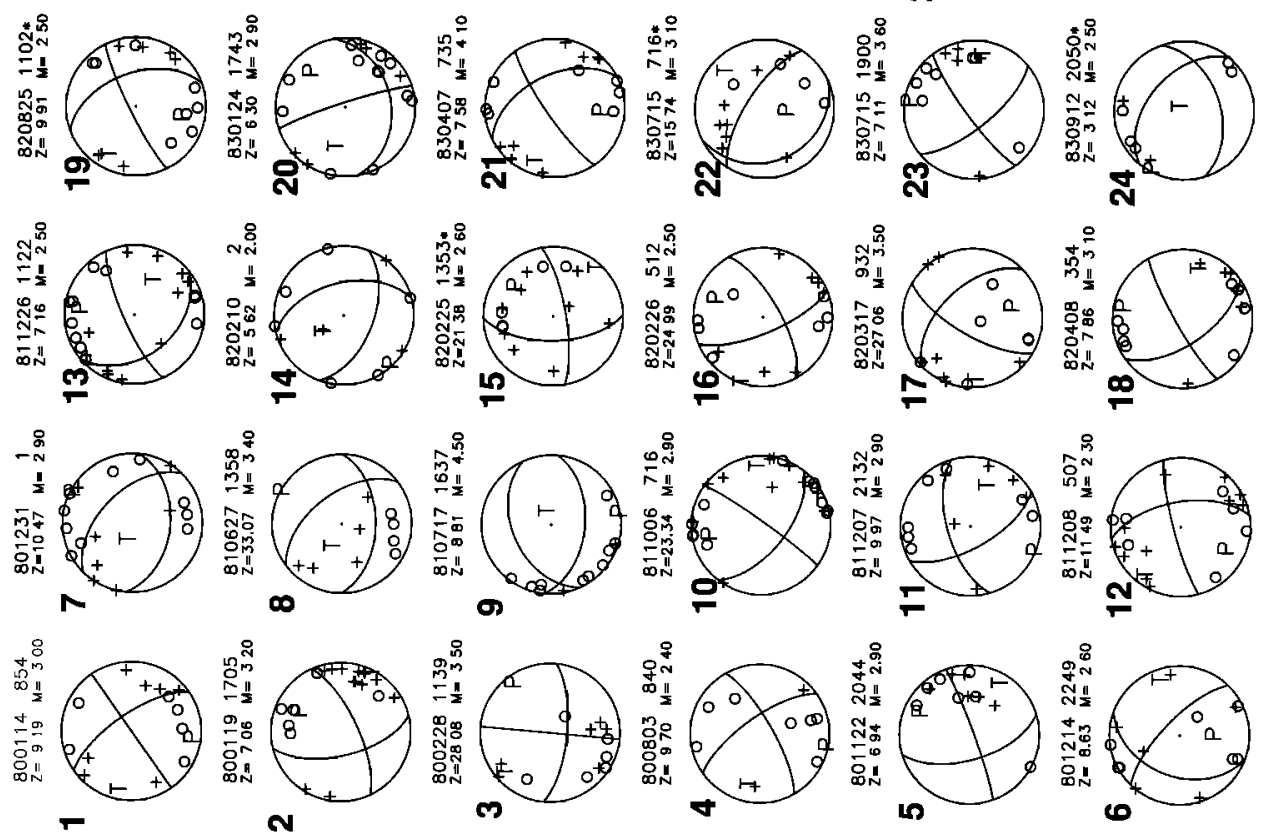


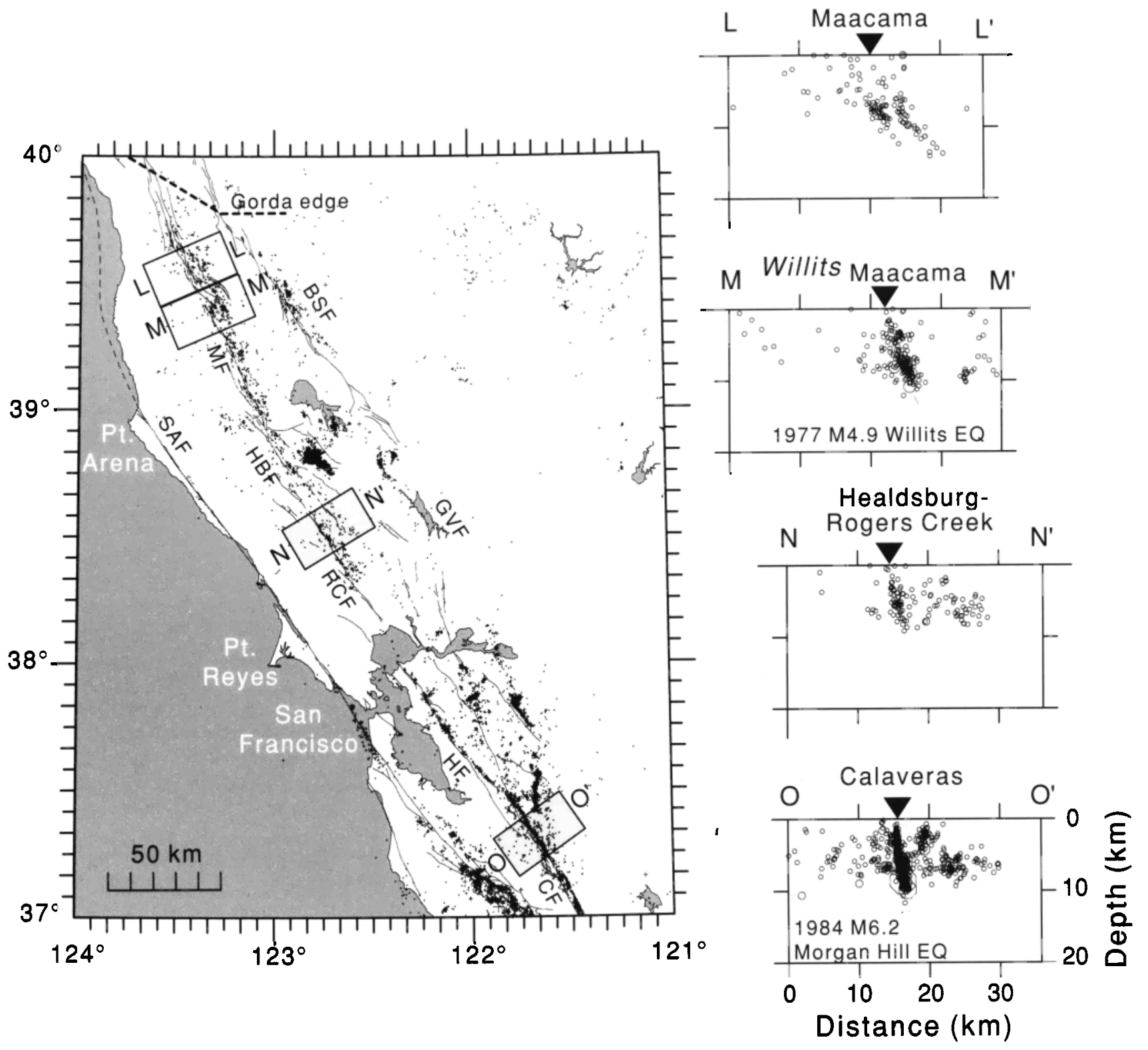

Fig. 11. Regional seismicity of the northern San Andreas fault (SAF) system for the 1980-1991 period. Profiles L-L' and $\mathbf{M}-\mathbf{M}^{\prime}$ along the Maacama fault (MF) are similar to profiles $\mathrm{G}^{-\mathrm{G}^{\prime}}$ and $\mathrm{H}-\mathrm{H}^{\prime}$, respectively, in Figure 9. Profiles $\mathbf{N}-\mathbf{N}^{\prime}$ and O-O' are along the Rodgers Creek-Healdsburg faults (RCF-HBF) and the Calaveras faults (CF), respectively. BSF, Bartlett Springs fault; GVF, Green Valley fault.

Near the eastern reaches of the Cascadia forearc region, Gorda slab earthquakes nucleating at $>20 \mathrm{~km}$ depths (e.g., earthquakes 32 and 42), show northeast directed $P$ axes and subhorizontal $T$ axes (Figures 5 and 6), indicating that the area is responding in a limited manner to both the North American/Pacific plate motion and North American/Gorda plate motion (Figures 5 and 6). Geodetic evidence based on historical triangulation, trilateration, and more recently, a Global Positioning System network just east of Cape Mendocino and within Round Valley shows that the azimuth of maximum shear for the $1980-1989$ period is consistent with right-lateral shear on northwest striking planes [Breen et al., 1987; Lisowski and Prescott, 1989; M. Lisowski, USGS, oral communication, 1991].

The spatial evolution of the Maacama, Rodgers Creek,
Healdsburg, Hayward, and Calaveras faults is depicted in Figure 11. Fault dips range from $50^{\circ}$ to $75^{\circ}$ along the northern reaches of the Maacama fault (profile $L$ ) to nearly vertical along the Calaveras fault (profile $\mathrm{N}$ ). Seismicity studies along the Rodgers Creek and Healdsburg faults [Wong, 1990] found these faults to dip $75^{\circ}-80^{\circ}$ to the northeast (profile $\mathrm{M}$ in Figure 11). The northeast dip of about $85^{\circ}$ along the Calaveras fault (profile $\mathbf{N}$ in Figure 11) is based on aftershock studies associated with the 1984 M6.2 Morgan Hill earthquake [Michael, 1988; Oppenheimer et al., 1988], while farther south, the San Andreas fault in Bear Valley is defined as a purely vertical structure [Ellsworth, 1975].

One possibility is that slip along the Hayward and Calaveras faults also originated along northeast dipping structures about $10 \mathrm{Ma}$, when the triple junction was located near 
the present latitude of San Francisco [Drake et al., 1989], but has subsequently evolved into a near-vertical fault. Steeper faults might develop as branches from the original dipping structure are more favorably oriented to accommodate plate motion [Michael, 1990]. Newly formed near-vertical faults, and the originally dipping structures, may jointly accommodate right-lateral motion until the near-vertical faults form an extensive fault zone. Presently, it appears that the Calaveras-Hayward-Rodgers Creek-Healdsburg faults form a single zone, unconnected to the southern end of the Maacama fault [Bilham and Bodin, 1992]. Where the faults zones appear not to be connected, the seismicity is diffuse (Figure 4), possibly because the moderately dipping fault planes are still in the process of forming vertical faults.

\section{Base of the Seismogenic Zone Along the MaACama and Bartlett Springs Faults}

With the northward passage of the Mendocino triple junction, thermal conditions within the North American plate along the Coast Ranges are altered due to the apparent upwelling of mantle material from the asthenosphere [Dickinson and Synder, 1979; Lachenbruch and Sass, 1980]. The magnitude of the Coast Range heat flow anomaly increases southward from the surface projection of the southern edge of the Gorda slab and reaches steady state conditions at about $200 \mathrm{~km}$ south of Cape Mendocino [Lachenbruch and Sass, 1973, 1977, 1980]. Lachenbruch and Sass [1980] modeled the heat flow with a "line source" located at a depth of about $20 \mathrm{~km}$ at the southern edge of the Gorda slab. In their model, the isotherms in the upper crust would shallow southward due to a time lag in the conductive heat transport mechanism. This effect may be inferred in the seismic data, which show a southward shallowing of the base of the seismogenic layer along the Maacama fault from $10-12 \mathrm{~km}$ near Laytonville to 8-10 km near Clear Lake (profile B in Figure 8). Secondary heat sources from the geothermal fields in The Geyers area and possibly from remnant magmatic activity associated with the Clear Lake volcanics might also contribute to the shallowing of the seismogenic zone near Clear Lake.

Alternatively, Miller and Furlong [1988] suggests that the depth to the base of the seismogenic zone is not thermally controlled, but is caused by a combination of low strain rate and low deviatoric stresses. Miller and Furlong [1988] interpret a slight depth increase in earthquakes in central California compared to northern California [see Hill et al., 1990, Figures 5.7 and 5.8] as an indication of low strain and low stress state in northern California. There is inconclusive evidence for comparing strain rates between the Hayward and Maacama fault segments [Lisowski and Prescott, 1989; Lisowski et al., 1991], although based on theoretical grounds of fault connectivity, the average slip rate along the Maacama may be $\sim 7 \mathrm{~mm} / \mathrm{yr}$ compared to $\sim 10 \mathrm{~mm} / \mathrm{yr}$ for the Hayward fault [Bilham and Bodin, 1992].

The base of the seismogenic zone along the Bartlett Springs fault reaches depths of up to $18 \mathrm{~km}$, significantly deeper than along the Maacama fault (Figures 8 and 9). Eastward deepening of the seismogenic zone from 12 to 18 $\mathrm{km}$ is similarly associated with the Hayward-CalaverasGreen Valley fault zones in the San Francisco Bay area [Ellsworth et al., 1982; Hill et al., 1990, 1991]. This regional deepening of seismicity to the east is consistent with an eastward decline in heat flow [Lachenbruch and Sass, 1973,
1977, 1980; Williams and Lachenbruch, 1991]. Alternatively, the deepening of the base of the seismogenic zone may reflect an eastward thickening of the North American plate either by a thicker accumulation of material within the Franciscan Complex to the east within the accretionary wedge, or by material thermally accreting to the base of the plate [Lachenbruch and Sass, 1980].

\section{Conclusions}

The development and evolution of the San Andreas fault system in northern California is closely tied to the northward migration of the Mendocino triple junction [Dickinson and Synder, 1979; Lachenbruch and Sass, 1973, 1980]. In particular, the abrupt decrease in the elastic thickness of the North American plate, south of the southern edge of the Gorda slab, acts to concentrate shear stresses, permitting transform-related slip along the most optimally oriented faults. For the inboard and youthful members of the San Andreas fault system, the initial North American/Pacific plate motion is being accommodated along the Maacama and Bartlett Springs faults. Seismicity along the Maacama and the Bartlett Springs fault zones is dominated by nearly pure strike-slip and oblique-reverse motion along fault planes that dip $50^{\circ}-75^{\circ}$ to the northeast. Although the seismicity associated with the Maacama and the Bartlett Springs faults terminates with the surface projection of the southern edge of the Gorda slab, the northward extrapolation of these faults is coincident with the Garberville and Lake Mountain faults, respectively. We infer from these observations that initial transform motion occurs along faults that had previously existed as reverse faults within the Cascadia forearc area. The southward continuity in the seismicity that includes the northeast dipping Maacama fault, the steeply dipping Healdsburg and Rodgers Creek faults, and the near-vertical Hayward and Calaveras faults indicates that the fault system evolves toward a vertical fault. Since a near-vertical fault minimizes the shear stresses that tends to resist plate motion, the apparent reorientation of these faults indicate that the Calaveras and Hayward fault zones currently reflect a more mature stage of fault development than does the Maacama fault.

Acknowledgments. We wish to thank G. Beroza, S. Clarke, Jr., K. Furlong, A. Griscom, B. Jachens, M. Magee, A. Michael, D. Oppenheimer, B. Page, N. Sleep, I. Wong, G. Zandt, and M. D. Zoback for their helpful suggestions for improving this manuscript. Discussions with D. Oppenheimer concerning the focal mechanism uniqueness test were especially insightful. D.A.C. was supported in part by the Graduate Intern Program of the U.S. Geological Survey.

\section{REFERENCES}

Aki, K., and P. G. Richards, Quantitative Seismology, vol. 1, Theory and Methods, 535 pp., W. H. Freeman, New York, 1980. Atwater, T., Plate tectonic history of the Pacific and western North America, in The Geology of North America, vol. N, The Eastern Pacific Ocean and Hawaii, edited by E. L. Winterer, D. M. Hussong, and R. W. Decker, pp. 21-72, Geological Society of America, Boulder, Colo., 1989.

Atwater, T., and P. Molnar, Relative motion of the Pacific and North American plates deduced from sea-floor spreading in the Atlantic, Indian, and South Pacific oceans, in Proceedings of the Conference on Tectonic Problems of the San Andreas Fault System, edited by R. L. Kovach and A. Nur, Stanford Univ. Publ. Geol. Sci., 13, 136-148, 1973. 
Bilham, R., and P. Bodin, Fault zone connectivity: Slip rates on faults in the San Francisco Bay Area, California, Science, 258, 281-284, 1992.

Bolt, B. A., and R. D. Miller, Catalogue of earthquakes in northern California and adjoining areas 1 January 1910-31 December 1972, 567 pp., Seismographic Stn. of the Univ. of Calif., Berkeley, 1975.

Breen, N. A., M. Lisowski, and W. H. Prescott, Spatially varying pattern of crustal strain near the Mendocino Triple junction, California (abstract), Eos Trans., 68, 1240, 1987.

Brown, R. D., and E. W. Wolf, Map showing recently active breaks along the San Andreas fault between Point Delgada and Bolinas Bay, California, 2 sheets, scale 1:24,000, U.S. Geol. Surv. Misc. Geol. Invest. Map, 1-692, 1972.

Clarke, S. H., Jr., Geology of the Eel River Basin and adjacent region: Implications for Late Cenozoic tectonics of the southern Cascadia subduction zone and Mendocino triple junction, $A A P G$ Bull., 76, 199-224, 1992.

Cockerham, R. S., Evidence for a 180-km-long subducted slab beneath northern California, Bull. Seismol. Soc. Am., 74, 569576, 1984.

Cox, A., and D. Engebretson, Changes in motion of Pacific plate at 5 Myr BP, Nature, 313, 472-474, 1985.

Curray, J. R., and R. D. Nason, The San Andreas fault north of Point Arena, California, Geol. Soc. Am. Bull., 78, 413-418, 1967.

Dehlinger, P., and B. Bolt, Seismic parameters along the Bartlett Springs fault zone in the Coast Ranges of northern California, Bull. Seismol. Soc. Am., 74, 1785-1798, 1984.

DeMets, C., R. G. Gordon, D. F. Argus, and S. Stein, Current plate motion, Geophys. J. Int., 101, 425-478, 1990.

Dewey, J. W., D. P. Hill, W. L. Ellsworth, and E. R. Engdahl, Earthquakes, faults, and the seismotectonic framework of the contiguous United States, in Geophysical Framework of the Continental United States, edited by L. C. Pakiser and W. D. Mooney, Mem. Geol. Soc. Am., 172, 541-575, 1989.

Dickinson, W. R., and W. S. Synder, Geometry of subducted slabs related to San Andreas transform, J. Geol., 87, 609-627, 1979.

Drake, D. E., D. A. Cacchione, J. V. Gardner, D. S. McCulloch, and D. Mason, Morphology and growth history of Delgada fan: Implications for the Neogene evolution of Point Arena basin and the Mendocino Triple junction, J. Geophys. Res., 94, 3139-3158, 1989.

Eberhart-Phillips, D., Three-dimensional velocity structure in northern California Coast Ranges from inversion of local earthquake arrival times, Bull. Seismol. Soc. Am., 76, 1025-1052, 1986.

Ellsworth, W. L., Bear Valley, California, earthquake sequence of February-March 1972, Bull. Seismol. Soc. Am., 65, 483-506, 1975.

Ellsworth, W. L., Historical Seismicity, in The San Andreas Fault System, edited by R. E. Wallace, U.S. Geol. Surv. Prof. Pap., $1515,115-152,1990$.

Ellsworth, W. L., A. G. Lindh, W. H. Prescott, and D. G. Herd, The 1906 San Francisco earthquake and the seismic cycle, in Earthquake Prediction: An International Review, Maurice Ewing Ser., edited by D. W. Simpson and P. G. Richards, pp. 126-140, AGU, Washington, D. C., 1981.

Ellsworth, W. L., J. A. Olsen, L. N. Shijo, and S. M. Marks, Seismicity and active faults in the eastern San Francisco Bay region, in Conference on Earthquake Hazards in the Eastern San Francisco Bay Area, Hayward, Calif., edited by E. W. Hart, S. E. Hirschfiled, and S. S. Schulz, Spec. Publ. Calif. Div. Mines and Geol., 62, 83-91, 1982.

Engebretson, D. C., A. Cox, and R. G. Gordon, Relative motions between oceanic and continental plates in the Pacific basin, Spec. Pap. Geol. Soc. Am., 206, 59 pp., 1986.

Furlong, K. P., W. D. William, and G. Zandt, Geometry and evolution of the San Andreas fault zone in northern California, $J$. Geophys. Res., 94, 3100-3110, 1989.

Griscom, A., and R. C. Jachens, Tectonic history of the northem portion of the San Andreas fault system, California, inferred from gravity and magnetic anomalies, J. Geophys. Res., 94, 3089-3099, 1989.

Harbert, W., and A. Cox, Late Neogene motion of the Pacific plate, J. Geophys. Res., 94, 3052-3064, 1989.

Hasegawa, A., D. Zhao, S. Hori, A. Yamamoto, and S. Horiuchi, Deep structure of the northeastern Japan arc and its relationship to seismic and volcanic activity, Nature, 352, 683-688, 1991.
Herd, D. G., and E. J. Helley, Faults with Quaternary displacement, northwestern San Francisco Bay region, California, scale 1:125,000, U.S. Geol. Surv. Misc. Field Stud. Map, MF-818, 1977.

Hill, D. P., J. P. Eaton, and L. M. Jones, Seismicity of the San Andreas fault system: 1980-1986, in The San Andreas Fault System, edited by R. E. Wallace, U.S. Geol. Surv. Prof. Pap., $1515,115-152,1990$.

Hill, D. P., J. P. Eaton, W. L. Ellsworth, R. S. Cockerham, F. W. Lester, and E. J. Corbett, The seismotectonic fabric of central California, in Neotectonics of North America, Decade Map vol. 1, edited by D. B. Slemmons, E. R. Engdahl, M. D. Zoback, and D. D. Blackwell, Geological Society of America, Boulder, Colo., 1991.

Jachens, R. C., and A. Griscom, Three-dimensional geometry of the Gorda plate beneath northern California, J. Geophys. Res., 88, 9375-9392, 1983.

Jennings, W. W., R. G. Strand, and R. W. Rogers, Geology map of California, scale 1:750,000, Calif. Div. of Mines and Geol., Sacramento, 1977.

Jones, D. L., M. C. Blake, Jr., E. H. Bailey, and R. J. McLaughlin, Distribution and character of Upper Mesozoic subduction complexes along the west coast of North America, Tectonophysics, 47, 207-222, 1978.

Kelsey, H. M., and G. A. Carver, Late Neogene and Quaternary tectonics associated with northward growth of the San Andreas transform fault, northern California, J. Geophys. Res., 93, 4797$4819,1988$.

Klein, F. W., User's guide to HYPOINVERSE, a program for VAX computers to solve for earthquake locations and magnitudes, U.S. Geol. Surv. Open File Rep., 89-314, 58 pp., 1989.

Klein, F. W., J. P. Eaton, and F. W. Lester, Seismic station data for northern California and surrounding area, U.S. Geol. Surv. Open File Rep., 88-448, 1988.

Knapp, J., S. W. Smith, K. McClain, and B. T. R. Lewis, Results of observations and earthquakes and explosions offshore of Cape Mendocino (abstract), Eos Trans. AGU, 59, 1133, 1978.

Kraadolfer, U., Seismische tomographie in der Schweiz mittels lockaler erdeben, Doktor der Naturwissenschften, 109 pp., Eidge. Tech. Hochsch. Zurich, 1989.

Lachenbruch, A. H., and J. H. Sass, Thermal-mechanical aspect of the San Andreas fault system, in Proceedings of the Conference on the Tectonic Problems of the San Andreas Fault System, edited by R. L. Kovach and A. Nur, pp. 192-205, Stanford University Press, Stanford, Calif., 1973.

Lachenbruch, A. H., and J. H. Sass, Heat flow in the United States and the thermal regime of the crust, in The Earth's Crust, Geophys. Monogr. Ser., vol. 20, edited by J. G. Heacock, pp. 626-675, AGU, Washington, D. C., 1977.

Lachenbruch, A. H., and J. H. Sass, Heat flow and energetics of the San Andreas fault zone, J. Geophys. Res., 85, 6185-6222, 1980.

Lawson, A. C., et al., The California earthquake of April 18, 1906, Report to the State Earthquake Commission, vol. 1, Carnegie Inst. Washington Publ. 87, 56-57, 1908.

Lisowski, M., and W. H. Prescott, Strain accumulation near the Mendocino Triple Junction, California (abstract), Eos Trans. $A G U, 70,1332,1989$.

Lisowski, M., J. C. Savage, and W. H. Prescott, The velocity field along the San Andreas fault in central and southern California, $J$. Geophys. Res., 96, 8369-8389, 1991.

McCulloch, D. S., Regional geology and hydrocarbon potential of the offshore central California, in Geology and Resource Potential of the Continental margin of Western North America and Adjacent Ocean Basins-Beaufort Sea to Baja California, Earth Sci. Ser., vol. 6, edited by D. W. Scholl, A. Grantz, and J. G. Vedder, pp. 353-401, Circum-Pacific Council for Energy and Mineral Resources, Houston, Tex., 1987.

McKenzie, D. P., and W. J. Morgan, Evolution of triple junctions, Nature, 224, 125-133, 1969.

McPherson, R. C., Seismicity and focal mechanisms near Cape Mendocino, northern California: 1974-1984, master thesis, 75 pp., Humboldt State Univ., Arcata, Calif., 1989.

Michael, A. J., Effects of three-dimensional velocity structure on the seismicity of the 1984 Morgan Hill, California, aftershock sequence, Bull. Seismol. Soc. Am., 78, 1199-1221, 1988.

Michael, A. J., Energy constraints on kinematic models of oblique 
faulting: Loma Prieta versus Parkfield-Coalinga, Geophys. Res. Lett., 17, 1453-1456, 1990.

Miller, C. K., and K. P. Furlong, Thermal-mechanical controls on seismicity depth distributions in the San Andreas fault zone, Geophys. Res. Lett., 15, 1429-1432, 1988.

Mount, V. S., and J. Suppe, State of stress near the San Andreas fault: Implication for wrench tectonics, Geology, 15, 1143-1146, 1987.

Oppenheimer, D. H., P. A. Reasenberg, and R. W. Simpson, Fault plane solutions for the 1984 Morgan Hill, California, earthquake sequence: Evidence for the state of stress on the Calaveras fault, J. Geophys. Res., 93, 9007-9026, 1988.

Pampeyan, E. H., P. W. Harsh, and J. M. Coakley, Preliminary map showing recently active breaks along the Maacama fault zone between Laytonville and Hopland, Mendocino County, California, scale 1:24000, U.S. Geol. Surv. Misc. Field Stud. Map, 1217, 1981.

Pollitz, F. F., Pliocene change in Pacific plate motion, Nature, 320 , 738-741, 1986.

Prentice, C., The Northern San Andreas fault: Russian River to Point Arena, in The San Andreas Transform Belt, edited by A. G. Sylvester and J. C. Crowell, Field Trip Guideb., vol. T309, pp. 49-51, AGU, Washington, D. C., 1989.

Reasenberg, P. A., and D. H. Oppenheimer, FPFIT, FPPLOT and FPPAGE: FORTRAN computer programs for calculating and displaying earthquake fault-plane solutions, U.S. Geol. Surv., Open File Rep., 85-739, 109 pp., 1985.

Riddihough, R., Recent movements of the Juan de Fuca plate system, J. Geophys. Res., 89, 6980-6994, 1984.

Roecker, S. W., Seismicity and tectonics of the Pamir-Hindu Kush region of Central Asia, 297 pp., Ph.D. thesis, Mass. Inst. of Technol., Cambridge, 1981.

Silver, E. A., Tectonics of the Mendocino triple junction, Geol. Soc. Am. Bull., 82, 2965-2978, 1971.

Simon, R. S., E. H. Pampeyan, and C. W. Stover, The Willits, California, magnitude 4.8 earthquake of November 22, 1977, U.S. Geol. Surv. Open File Rep. 78-1075, 24 pp., 1978.

Smith, S. W., and J. S. Knapp, The northern termination of the San Andreas fault, in Studies of the San Andreas Fault Zone in Northern California, edited by R. Streitz and R. S. Herburne, Spec. Rep. Calif. Div. Mines Geol., 140, 153-164, 1980.
Toppozada, T. R., and C. H. Cramer, Ukiah earthquake, 25 March 1978: Seismicity possibly induced by Lake Mendocino, Calif. Geol., 31, 275-281, 1978.

Upp, R. R., Holocene activity on the Maacama fault, Mendocino County, California, Ph.D. thesis, 112 pp., Stanford Univ., Stanford, Calif., 1982.

Walter, A. W., and W. D. Mooney, Crustal structure of the Diablo and Gabilan Ranges, Central California: A reinterpretation of existing data, Bull. Seismol. Soc. Am., 72, 1567-1590, 1982.

Walter, S. R., Intermediate-focus earthquakes associated with Gorda plate subduction in northern California, Bull. Seismol. Soc. Am., 76, 583-588, 1986.

Walter, S., and D. Dzurisin, The September 1988 Earthquake swarm at Medicine Lake Volcano, northern California (abstract), Eos Trans. AGU, 70, 1189, 1989.

Warren, D. H., C. Scofield, and C. Bufe, Aftershocks of the 22 November 1977 earthquake at Willits, California: Activity in the Maacama fault zone, Bull. Seismol. Soc. Am., 75, 505-517, 1985.

Williams, C. F., and A. H. Lachenbruch, The San Andreas fault geotherm revisited (abstract), Eos Trans. AGU, 72(44), Fall Meeting suppl., 443, 1991.

Wong, I. G., Contemporary seismicity, active faulting and seismic hazards of the Coast Ranges between San Francisco Bay and Healdsburg, California, Bull. Seismol. Soc. Am., 80, 935-950, 1990.

Zoback, M. D., M. L. Zoback, V. S. Mount, J. Suppe, J. P. Eation, J. H. Healy, D. Oppenheimer, P. Reasenberg, L. Jones, C. B. Raleigh, I. G. Wong, O. Scotti, and C. Wentworth, New evidence on the state of stress of the San Andreas fault system, Science, 238, 1105-1111, 1987.

D. A. Castillo, Department of Geophysics, Stanford University, Stanford, CA 94305-2215.

W. L. Ellsworth, U.S. Geological Survey, MS 977, 345 Middlefield Road, Menlo Park, CA 94025.

(Received February 27, 1992; revised November 5, 1992; accepted December 4, 1992.) 